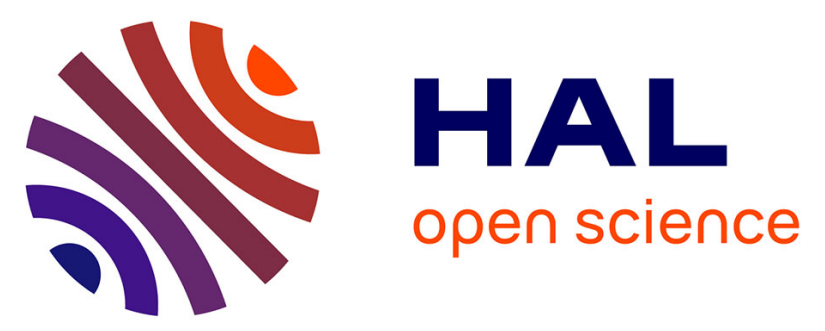

\title{
Microfossils with tail-like structures in the 3.4 Gyr old Strelley Pool Formation Authors
}

Frédéric Delarue, Sylvain Bernard, Kenichiro Sugitani, François Robert, Romain Tartèse, Sonja-Verena Albers, Rémi Duhamel, Sylvain Pont, Sylvie

Derenne

\section{To cite this version:}

Frédéric Delarue, Sylvain Bernard, Kenichiro Sugitani, François Robert, Romain Tartèse, et al.. Microfossils with tail-like structures in the 3.4 Gyr old Strelley Pool Formation Authors. Precambrian Research, 2021, 358, pp.106187. 10.1016/j.precamres.2021.106187 . hal-03349816

\section{HAL Id: hal-03349816 https://hal.sorbonne-universite.fr/hal-03349816}

Submitted on 20 Sep 2021

HAL is a multi-disciplinary open access archive for the deposit and dissemination of scientific research documents, whether they are published or not. The documents may come from teaching and research institutions in France or abroad, or from public or private research centers.
L'archive ouverte pluridisciplinaire HAL, est destinée au dépôt et à la diffusion de documents scientifiques de niveau recherche, publiés ou non, émanant des établissements d'enseignement et de recherche français ou étrangers, des laboratoires publics ou privés. 
Authors

4

Frédéric Delarue ${ }^{\mathrm{a} *}$, Sylvain Bernard ${ }^{\mathrm{b}}$, Kenichiro Sugitani $^{\mathrm{c}}$, François Robert ${ }^{\mathrm{b}}$, Romain Tartèse ${ }^{\mathrm{d}}$,

Sonja-Verena Albers ${ }^{\mathrm{e}, \mathrm{f}}$, Rémi Duhamel ${ }^{\mathrm{b}}$, Sylvain Pont ${ }^{\mathrm{b}}$, Sylvie Derenne ${ }^{\mathrm{a}}$

6

7

8

9

\section{Affiliations}

a'Sorbonne Université, CNRS, EPHE, PSL, UMR 7619 METIS, 4 place Jussieu, F-75005 Paris,

France

${ }^{\text {b} M u s e ́ u m ~ N a t i o n a l ~ d ' H i s t o i r e ~ N a t u r e l l e, ~ S o r b o n n e ~ U n i v e r s i t e ́, ~ U M R ~ C N R S ~ 7590, ~ I R D, ~ I n s t i t u t ~}$ de Minéralogie, de Physique des Matériaux et de Cosmochimie, IMPMC, 75005 Paris, France ${ }^{\mathrm{c}}$ Department of Earth and Environmental Sciences, Graduate School of Environmental Studies, Nagoya University, Nagoya, Japan

${ }^{\mathrm{d} D e p a r t m e n t ~ o f ~ E a r t h ~ a n d ~ E n v i r o n m e n t a l ~ S c i e n c e s, ~ T h e ~ U n i v e r s i t y ~ o f ~ M a n c h e s t e r, ~ M a n c h e s t e r ~}$ M13 9PL, United Kingdom

${ }^{e}$ Molecular Biology of Archaea, Institute of Biology II, Faculty of Biology, University of Freiburg, Freiburg, Germany.

fSpemann Graduate School of Biology and Medicine, University of Freiburg, Freiburg, Germany.

*Correspondence to: frederic.delarue@upmc.fr 


\section{Abstract}

Some of the oldest traces for planktonic lifestyle have been reported in ca. 3.4 billion years old silicified sediments from the Strelley Pool Formation in Western Australia. Observation of flange appendages suggests that Archean life motility was passive and driven by drifting of microorganisms in their surrounding environment. Until now, the oldest traces for active motility are ca. 2.1 billion years old. Whether or not active motility already existed during the Archean eon remains an open question. In this study, we report the discovery of new 3.4 billion years old microfossils exhibiting a tail-like structure isolated from the Strelley Pool Formation. Exhibiting Raman spectra typically observed in organic-walled microfossils from the Strelley Pool Formation, these microfossils exhibiting a tail-like structure are syngenetic with their host rock. Composed of carbon, nitrogen, and, for one specimen, phosphorus, some of these organicwalled microfossils also exhibit significant level of aliphatic and amide moieties supporting their biogenicity. In addition, these microfossils exhibit a tail-like appendage sharing similar morphological features with locomotory organelles in modern microorganisms such as archaella, flagella, and cilia. This suggests that this observed appendage likely provided them with movement capabilities. If correct, with the ability to move, these microorganisms were capable of escaping from harsh environments and/or colonizing new ecological niches as early as 3.4 billion years ago.

\section{Keywords}

Archean - Early life - Morphology - NanoSIMS - Raman spectroscopy - Strelley Pool

\section{Introduction}

Archean carbonaceous microfossils testify for the widespread presence of life on Earth as early as ca. 3.4 billion years ago (Westall et al., 2006; Sugitani et al., 2010; Wacey et al., 2011; Alleon et al., 2018). However, the interpretation of the Archean palaeobiological record is fraught with 
difficulties pertaining to fossilization and burial-induced degradation processes, as exemplified by intense debates over the past couple of decades (e.g., Schopf et al., 2002; Brasier et al., 2002; Wacey et al., 2016). Remnants of early life forms have experienced burial and thermal alteration for billions of years, which led to the degradation of many pristine biological traits (Javaux et al., 2019). Archean putative microfossils tend to exhibit simple morphological shapes at the micrometric scale (e.g., spheroidal, filamentous, film, and lenticular forms) that can also be abiotically produced (Garcia-Ruiz et al., 2003; Cosmidis et al., 2016), precluding, in turn, any simple morphological distinction between genuine biological remnants and mineral/organic biomorphs. Because of the lack of taxonomically informative features (Javaux et al., 2019), morphological criteria alone are generally considered as insufficient to assess the biological nature of ancient traces of life in the Archean geological record (Brasier et al., 2006). As a result, the ancient fossil record has not yet conveyed a complete picture of ancient biodiversity. Here, we report the discovery of 3.4 billion years old organic microfossils from the Strelley Pool Formation (SPF) exhibiting exceptionally preserved morphological traits possibly indicative of active motility. 


\section{Material and methods}

\subsection{Studied sample}

For this study, we selected a 3.4 billion year-old black chert sampled from the Panorama locality (PANX1-1) situated in the SPF (Western Australia), and which displays abundant microfossils and microscopically identifiable parallel laminations (see Sugitani et al., 2010, 2013, and 2015 for detailed description of the geological background).

\subsection{Chemical isolation of microfossils}

Organic-walled microfossils were isolated from the SPF carbonaceous black chert sample using a modified version of the classical acid maceration procedure (Delarue et al., 2020). A 'soft' acid maceration procedure was applied in order to minimize both potential physical and chemical degradation of organic microstructures. Prior to acid maceration, about $30 \mathrm{~g}$ of rock samples were fragmented into $\sim 3$ g rock chips rather than crushed into finer grains. Rock chips were cleaned using ultrapure water and a mixture of dichloromethane/methanol (v/v: $2 / 1)$, and were then directly placed in a Teflon vessel filled with a mixture of HF ( $40 \%$, reagent grade) / $\mathrm{HCl}(37 \%$; reagent grade; v/v: 9/1) at room temperature. After 48 hours, successive centrifugation and rinsing steps using ultrapure water were performed until reaching neutrality. The residual material was suspended in ethanol and filtered on polycarbonate filters (pore $\varnothing=$ $10 \mu \mathrm{m})$. After ethanol evaporation, polycarbonate filters were fixed on carbon tape and coated with $20 \mathrm{~nm}$ of gold to prevent further contamination by atmospheric deposits and for further analyses.

2.3. Scanning electron microscopy and Energy Dispersive X-Ray Spectroscopy (SEMEDXS) 
SEM-EDXS imaging and analysis were performed on gold-coated filters using a TESCAN VEGA II at the French National Museum of Natural History (MNHN) operated with an accelerating voltage of $15 \mathrm{kV}$.

\subsection{Raman spectroscopy}

Raman microspectroscopy was carried out using a Renishaw InVIA microspectrometer equipped with a $532 \mathrm{~nm}$ green laser. The laser was focused on the sample by using a DMLM Leica microscope with a $50 \times$ objective. The spectrometer was first calibrated with a silicon standard before the analytical session (matching at $520.5 \mathrm{~cm}^{-1}$ ). For each target, we determined the Raman shift intensity in the 1000 to $2000 \mathrm{~cm}^{-1}$ spectral window that includes the first-order defect (D) and graphite (G) peaks. A laser power below $1 \mathrm{~mW}$ was used to prevent any thermal alteration during spectrum acquisition. Spectrum acquisition was achieved after three iterations using a time exposure of 10 seconds (spectral resolution of $1.5 \mathrm{~cm}^{-1}$ ). Raman microspectroscopy was performed on gold-coated organic surfaces, implying a slight lowering of the relative intensity of the $\mathrm{D}$ band with respect to the $\mathrm{G}$ one (Delarue et al. 2020).

\subsection{Nanoscale secondary ion mass spectrometry}

Isolated microfossils were analyzed using a CAMECA NanoSIMS 50 ion probe using a $\mathrm{Cs}^{+}$ primary ion beam. Before measurements, pre-analysis sputtering was performed over $30 \times 30$ $\mu \mathrm{m}^{2}$ areas for ca. 8 minutes using a $500 \mathrm{pA}$ primary current (750 $\mu \mathrm{m}$ aperture diaphragm) to remove surficial contamination, and achieve $\mathrm{Cs}^{+}$saturation fluence and constant secondary ion count rates. Analyses were then carried out using a $10 \mathrm{pA}$ primary current $(200 \mu \mathrm{m}$ aperture diaphragm) on smaller areas to avoid pre-analysis sputtering edge artifacts. The secondary molecular species ${ }^{12} \mathrm{C}^{14} \mathrm{~N}^{-}$and ${ }^{31} \mathrm{P}^{-}$were collected simultaneously in electron multipliers. The 
NanoSIMS raw data were corrected for a 44 ns dead time on each electron multiplier and processed using the Limage software.

\subsection{Focused ion beam (FIB)}

FIB ultrathin sections were extracted from the organic microfossils using an FEI Strata DB 235 (IEMN, Lille, France). Milling at low gallium ion currents minimizes common artefacts, including local gallium implantation, mixing of components, creation of vacancies or interstitials, creation of amorphous layers, redeposition of the sputtered material on the sample surface, and significant changes in the speciation of carbon-based polymers.

\subsection{Scanning transmission X-ray microscopy (STXM)}

X-ray Absorption Near Edge Structure (XANES) investigations were conducted using the HERMES STXM beamline at the synchrotron SOLEIL (Gif-sur-Yvette, France). Carbon contamination on beamline optics was constantly removed thanks to a continuous flow of pure $\mathrm{O}_{2}$. The well-resolved 3p Rydberg peak of gaseous $\mathrm{CO}_{2}$ at $294.96 \mathrm{eV}$ was used for energy calibration. Collecting image stacks at energy increments of $0.1 \mathrm{eV}$ with a dwell time of $\leq 1 \mathrm{~ms}$ per pixel prevented irradiation damage. The estimations of $\mathrm{N} / \mathrm{C}$ values and the normalization of the C-XANES spectra shown here were done using QUANTORXS (Le Guillou et al., 2018).

\section{Results and Discussion}

Microscope observations of the studied SPF sample thin sections revealed the presence of organic-walled microfossils exhibiting a tail-like structure (Fig. 1a, b). These microfossils are exclusively observed within the siliceous sedimentary matrix, precluding their introduction during hydrothermal fluid circulation post $3.4 \mathrm{Ga}$. 

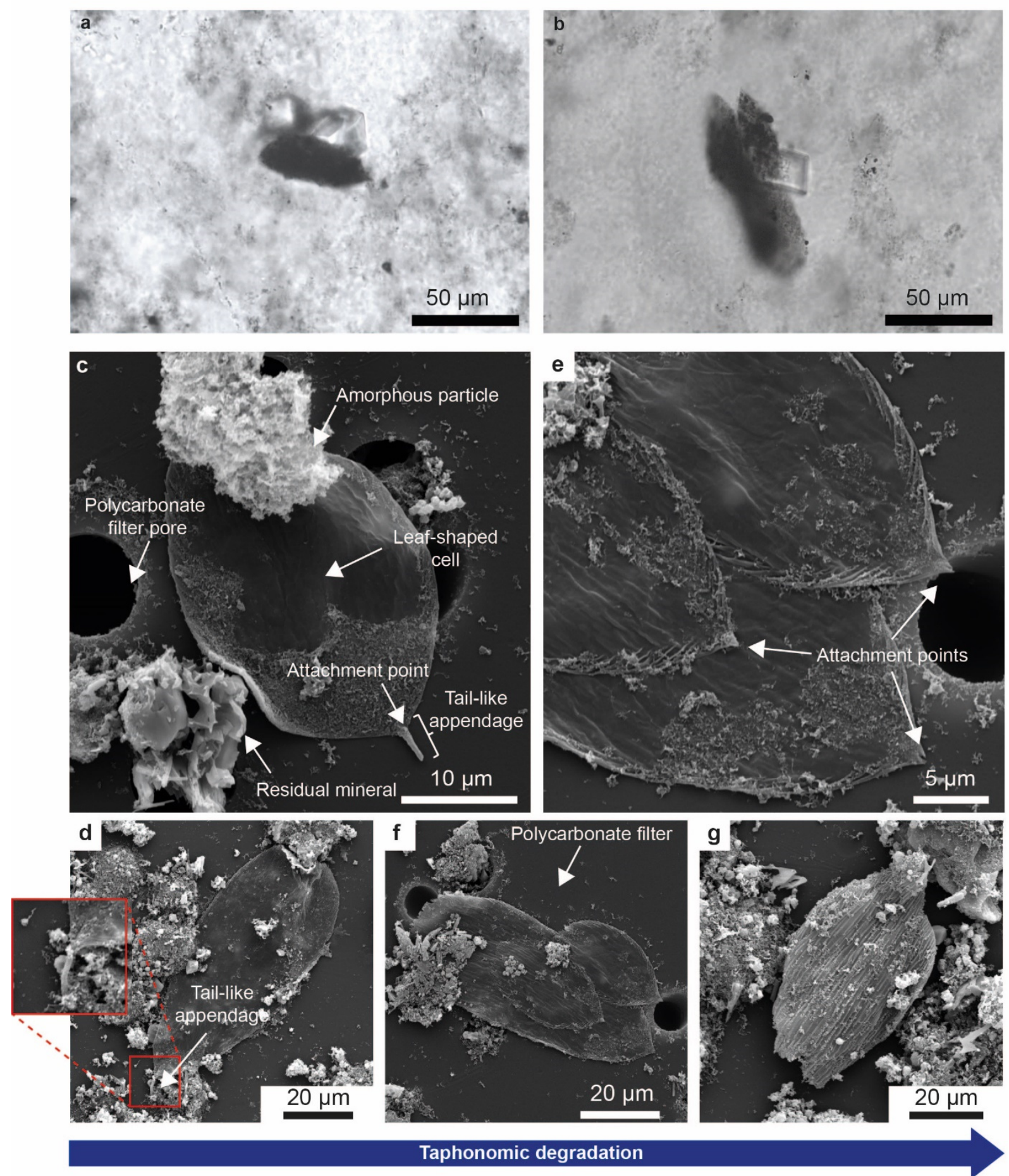

142 Figure 1: Thin section micrographs and scanning electron microscopy images of organic microfossils exhibiting or not a tail-like structure. (a) Micrograph presenting a microfossil exhibiting a tail-like structure embedded in the main siliceous matrix of the studied SPF chert. (b) Micrograph presenting a microfossil exhibiting no tail-like structure. (c-f) SEM images of organic microfossils exhibiting or not a tail-like structure isolated by acid maceration. $(\mathrm{c}, \mathrm{d})$ Exceptionally-well preserved leaf-shaped cells presenting a locomotory organelle composed of an attachment point and of a tail; (e-g) Corresponding degraded organic-walled microfossils lacking a tail but (e, f) exhibiting an attachment point. Comparison between microfossils 
173 a biological origin. observed.

exhibiting a tail-like structure and microfossils presenting an attachment point suggests that tails may be lost during taphonomy. A taphonomic degradation gradient is observed from the left to the right. Classic taphonomical degradation features, including folds and tears, are

Raman spectra of specimens exhibiting a tail-like structure chemically isolated from the siliceous matrix are typical of those of disordered carbonaceous materials having undergone a low-grade metamorphism (Fig. 2a; Pasteris and Wopenka, 2003). Their Raman line shapes suggest that these microfossils experienced hydrothermal and/or diagenetic peak temperatures of approximately $250-300{ }^{\circ} \mathrm{C}$ (Lahfid et al., 2010; Kouketsu et al., 2014). Raman first-order spectra of the studied SPF microfossils exhibiting a tail-like structure are similar to those previously determined on syngenetic microfossils from the same geological formation observed in thin sections (Lepot et al., 2013; Sugitani et al., 2013), on freshly fractured faces (Alleon et al., 2018), and in acid maceration residue (Delarue et al., 2020). Therefore, these organic-walled microfossils exhibiting a tail-like structure should be regarded as syngenetic as they were subjected to the maximum metamorphic temperature registered by their host rock.

Although Raman spectroscopy is a useful tool to assess syngeneity, it is not sufficient to determine the biogenicity of putative remains of ancient life (Pasteris and Wopenka, 2003). Energy-dispersive X-ray spectroscopy data show that the studied specimens essentially contain $\mathrm{C}$ and $\mathrm{O}$ (Fig. 2b), confirming their organic nature, while nanoscale secondary ion mass spectrometry reveals the presence of nitrogen and, in one specimen, phosphorus (Figs. 2d, f-g). The presence of these key elements of cell walls, proteins, and nucleic acids are consistent with 


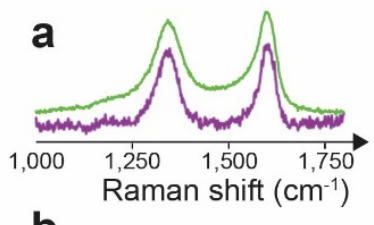

b
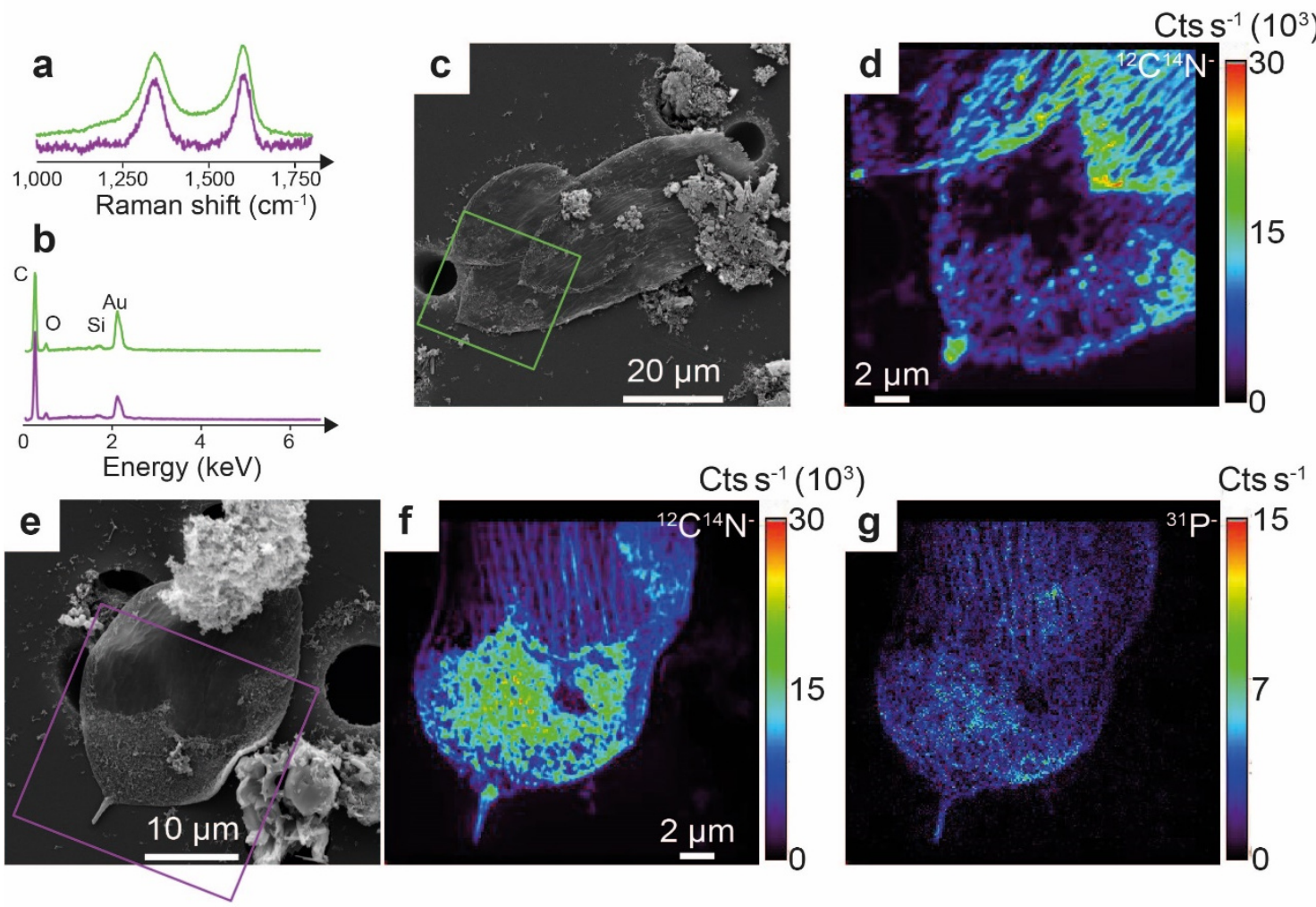

Figure 2: Raman spectra, energy-dispersive $X$-ray spectra, and nanoscale secondary ion mass spectrometry images. (a) First-order Raman spectra determined on isolated organic microfossils exhibiting a tail-like structure and (b) corresponding energy-dispersive X-ray spectra. Green and purple lines indicate that spectra were acquired on specimens shown in panels c and e, respectively. (c, e) SEM images of organic-walled microfossils investigated by EDXS, Raman spectroscopy and NanoSIMS. Green and purple squares indicate areas probed by NanoSIMS. $(\mathrm{d}, \mathrm{f})$ The ${ }^{12} \mathrm{C}^{14} \mathrm{~N}^{-}$ion images illustrate the presence of nitrogen. $(\mathrm{g})$ The ${ }^{31} \mathrm{P}^{-}$ image illustrates the presence of phosphorus. No ${ }^{31} \mathrm{P}^{-}$was recorded on the second specimen shown in panel c. Variations in ${ }^{31} \mathrm{P}^{-}$emission intensity between the smooth (e.g., microfossil itself) and rough (e.g., coating by amorphous submicrometric organic matter) surfaces cannot be used to depict any $\mathrm{P}$ enrichment because of microtopographic features biasing ion emissions (Delarue et al., 2017).

Spatially resolved chemical investigations exploiting X-ray absorption confirm the heterogeneous chemical nature of the investigated organic-walled microfossils: at least three different types of chemical structures could be distinguished within a given specimen (Fig. 3).

192 Specimens contain some highly graphitic organic materials with almost no nitrogen as revealed by X-ray absorption spectra exhibiting a broad peak of conjugated aromatic groups $(285.5 \mathrm{eV})$ and the excitonic absorption feature of planar domains of highly conjugated $\pi$ systems $(291.7$ 
eV; Bernard et al., 2010). Closely associated are N-poor materials with XANES spectra similar

196 to those of thermally-altered kerogen with an intense absorption peak at $285 \mathrm{eV}$ (aromatic or

197 olefinic groups), a relatively broad absorption feature at $287.5 \mathrm{eV}$ (aliphatic carbons), and an

198 absorption feature at $286.6 \mathrm{eV}$ (imine, nitrile, carbonyl and/or phenol groups; Bernard et al.,

199 2010; Le Guillou et al., 2018). Specimens also contain N-rich compounds (N/C 0.22) with

200 XANES spectra that exhibit clear contributions of quinones or cyclic amides $(284.5 \mathrm{eV})$,

201 aromatic or olefinic carbons $(285.1 \mathrm{eV})$, imine, nitrile, carbonyl and/or phenol groups (286.6

$202 \mathrm{eV})$, aliphatics $(287.7 \mathrm{eV})$ and amides $(288.2 \mathrm{eV})$. Altogether, the chemical structure of the SPF

203 specimen investigated here is consistent with the preservation of partially degraded

204 biomolecules.
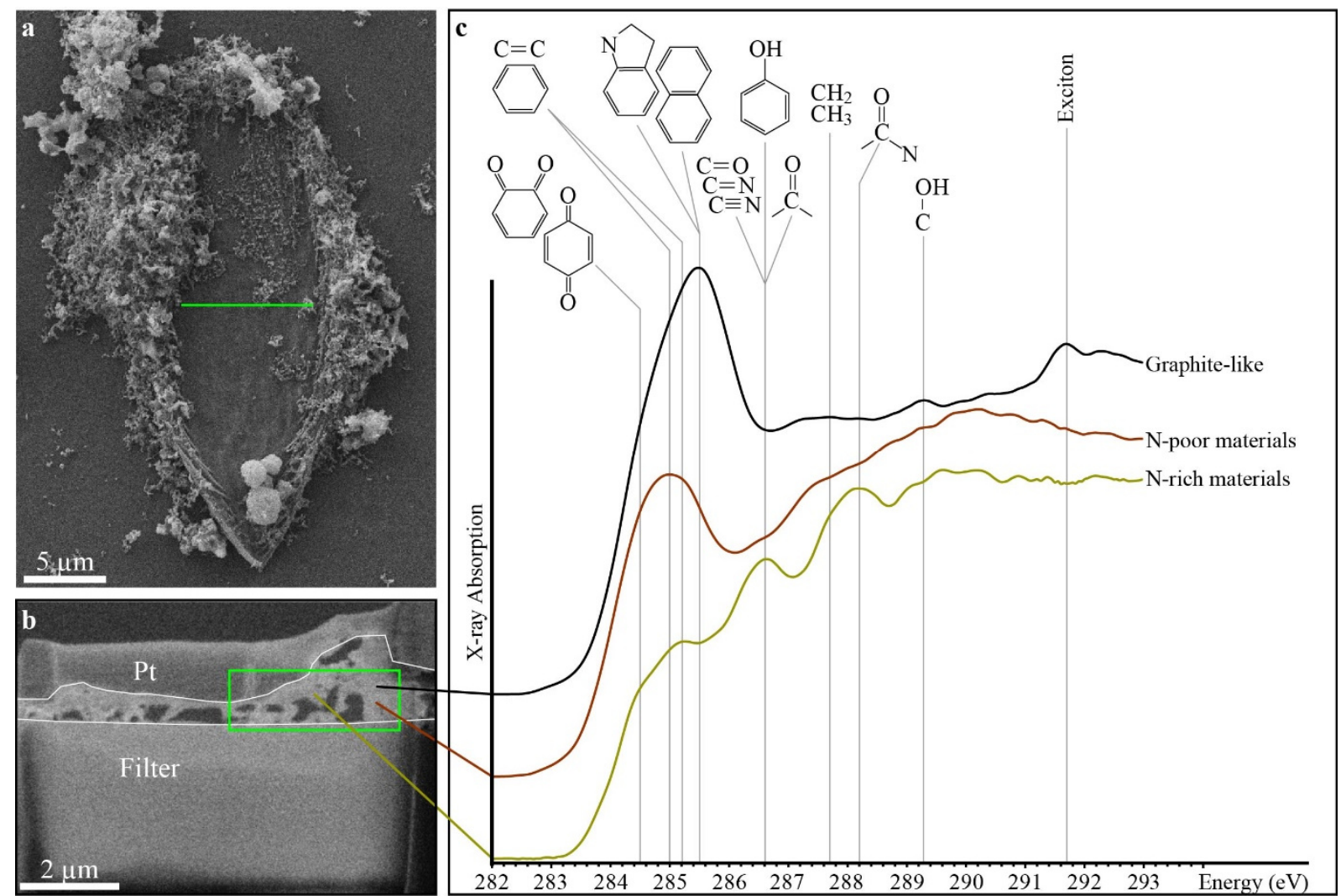

$\begin{array}{lllllllllllll}282 & 283 & 284 & 285 & 286 & 287 & 288 & 289 & 290 & 291 & 292 & 293 & \text { Energy (eV) }\end{array}$

Figure 3: Scanning transmission X-ray microscopy-based X-ray absorption near edge structure characterization. (a) SEM image of the specimen from which a focused ion beam foil has been extracted (green line). (b) SEM image of the focused ion beam foil evidencing the limited thickness of the specimen. The green square indicates the area investigated using 
STXM. (c) Carbon-X-ray absorption near edge structure spectra of the organic materials composing the investigated specimen.

From a morphological point of view, the organic-walled microfossils are leaf-shaped cells ranging from 30 to $84 \mu \mathrm{m}$ in length and from 16 to $37 \mu \mathrm{m}$ in width (Fig. 1). They exhibit classic taphonomical degradation features, including folds and tears (Figs. 1c-g). The preparation of ultrathin foils using focused ion beam illustrates their relative limited thickness, ranging from 200 to $500 \mathrm{~nm}$ (Fig. 3). Four specimens also exhibit a specific morphological feature: a tail-like appendage protruding from the leaf-shaped cell (Figs. 1c, d).

From the comparison with modern microorganisms, we can assume that this tail-like appendage is a remnant of an ancient prostheca or of a locomotory organelle. The tail-like appendages observed in SPF microfossils are between 0.7 and $1.2 \mu \mathrm{m}$ in diameter, which is, by far, larger than those reported for modern archaella, flagella, and cilia, reaching ca. 10, 20, and $200 \mathrm{~nm}$, respectively (Jarell and McBride, 2008; Beeby et al., 2020). This would be forgetting that Precambrian organic-walled microfossils exhibit very large cell dimensions $(\varnothing>10 \mu \mathrm{m})$ compared to modern microorganisms (Javaux et al., 2010; Sugitani et al., 2010; 2015; Balidukay et al., 2016; Loron et al., 2019.

In order to take this difference into account, we propose to use the Appendage Shape Index (ASI), which is based on the ratio between the width of the tail-like appendage and that of the parent cell (Fig. 4). Compilation of morphometric data from extant microorganisms shows that prosthecae and locomotory organelles are characterized by different ASI values. Prosthecae display ASI values ranging from 13 to $39 \%$ while they range from 1 to $10 \%$ for modern archaella, flagella, and cilia (Fig. 4; see supplementary information for detailed values). In the 
present study, the tail-like appendages are characterized by ASI values ranging from 2 to $6 \%$, that is values falling within the domain of modern archaella, flagella, and cilia (Fig. 4).

Involved in anchoring cells to organic and mineral surfaces, in nutrient uptake, or in asexual reproduction by budding at its tip (Curtis, 2017), a prostheca is a micrometric tube-like appendage consisting in an extension of the cellular membrane. This implies a structural continuity between the microorganism body and the base of the prostheca (Javaux et al., 2003). Here, the SPF specimens investigated exhibit an anchoring attachment point and a filament-like appendage, indicating two distinct structural subunits (Fig. 1) at odds with any extension of the cellular membrane. Because of their ASI values and their two structural subunits, the tail-like appendages observed in SPF microfossils cannot be considered as remnants of prosthecae.

As far as we are aware, occurrence of distinct external and functional subunits can only be assigned to locomotory organelles, in good agreement with ASI values. However, these subunits do not meet standard structural features (for instance, a curved hook connecting the filament to the basal body in flagella) observed on locomotory organelles from any organism of the three extant domains of life (see Khan and Scholey, 2018) implying in turn, that the observed structural features do not allow to depict the biological affinity of these remnants of tailed microorganisms.. 


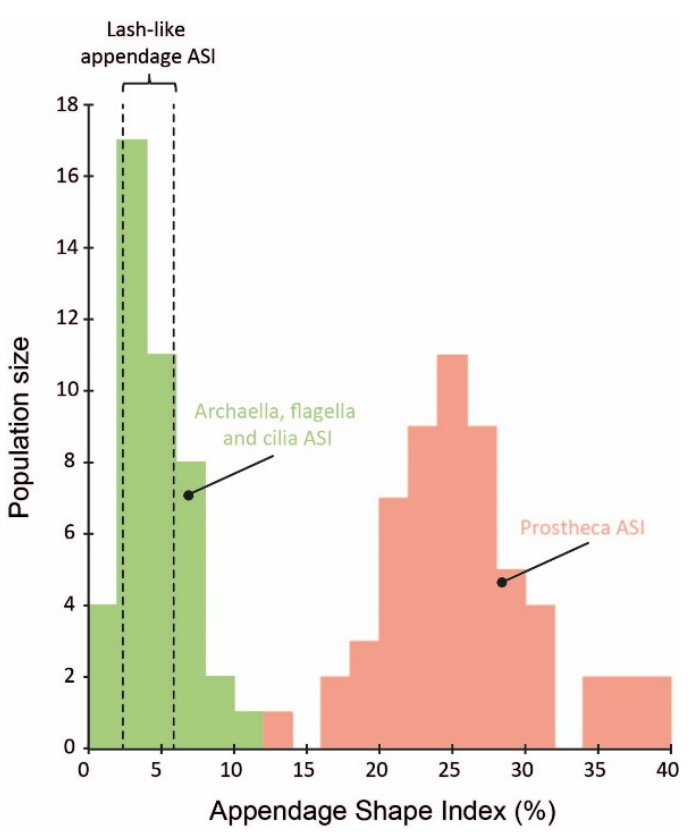

Figure 4: Compilation of Appendage Shape Indices determined on extant microorganisms and on studied microfossils. ASI was computed according to the ratio between the width of appendage (archaellum, flagellum, cilium and prostheca) and that of its parent cell $(\times 100)$. Each width of appendage and of its parent cell was determined graphically based on micrographs and images published in Southam et al. (1990), Poindexter and Staley (1996), Furuno et al. (1997), Wustman et al. (1997), Quintero et al. (1998), Wang et al. (2000), Miller et al. (2004), Bergholtz et al. (2006), Vasilyeva et al. (2006), Wagner et al. (2006), Kanbe et al. (2007), Abraham et al. (2008), Nge et al. (2008), Pyatibratov et al. (2008), Siano et al. (2009), Craveiro et al. (2010), Wang et al. (2011), Abraham and Rohde (2014), Lim et al. (2014), Albers and Jarrell (2015), Deng et al. (2016), Kinosita and Nishizaka (2016), Sugitomo et al. (2016), Curtis (2017), and Leander et al. (2017; (see supplementary information)). ASI determined on archaella, flagella, and cilia are indicated in green while those determined on prosthecae are indicated in pink. The area delimited by dotted lines indicate ASI determined on four tail-like appendages observed on SPF organic-walled microfossils. ASI ranges from 4.8 to $5.8 \%$ and from 2.2 to $3.3 \%$ in organic-walled microfossil observed in thin sections $(\mathrm{n}=2)$ and in the acid maceration residue $(n=2)$, respectively. ASI is likely overestimated in thin sections as a consequence of shadows occurring at the edge of microfossils.

Previous reports of 3.4-3.0 Ga lenticular microfossils exhibiting a flange were interpreted as demonstrating passive motility of microbial planktons drifting depending on their surrounding environment (House et al., 2013; Sugitani et al., 2015; Oehler et al., 2017; Kozawa et al., 2019). To date, the oldest evidence for active motility was recorded as tubular sedimentary structures in 2.1 Ga Francevillian sedimentary series in Gabon (El Albani et al., 2019). The preservation of tail-like structures by some SPF microfossils suggests that some microorganisms could have 
been capable of active motility - a mechanism whereby microorganisms can direct their movement - as early as 3.4 Gyr ago. Since it likely provided them with the ability to move in the water column or at the surface of organic and/or mineral surfaces, this finding suggests that microorganisms were possibly able to escape harsh environments, adapt their feeding strategies moving towards more favorable nutrient sources, and colonize new ecological niches less than a billion years after the Earth became habitable.

\section{Acknowledgments}

We thank D. Troadec (IEMN) for FIB extraction. We also acknowledge The National NanoSIMS Facility at the MNHN, supported by MNHN, CNRS, Région Ile de France, and Ministère de l'Enseignement Supérieur et de la Recherche. Special thanks go to Stefan Stanescu and Sufal Swaraj for their expert support with the HERMES STXM beamline at SOLEIL. The HERMES beamline (SOLEIL) is supported by the CNRS, the CEA, the Region Ile de France, the Departmental Council of Essonne and the Region Centre. This work was supported by the Programme National de Planétologie (PNP) of CNRS/INSU, co-funded by CNES R.T. also acknowledges the UK Science and Technology Facilities Council (grant ST/P005225/1) for financial support. Authors are grateful to the associate editor and the two anonymous reviewers for their constructive comments.

\section{References}

Abraham, W.-R., Macedo, A.J., Lunsdorf, H., Fischer, R., Pawelczyk, S., Smit, J., Vancanneyt, M., 2008. Phylogeny by a polyphasic approach of the order Caulobacterales, proposal of Caulobacter mirabilis sp. nov., Phenylobacterium haematophilum sp. nov. and 
Phenylobacterium conjunctum sp. nov., and emendation of the genus Phenylobacterium.

305 International Journal of Systematic and Evolutionary Microbiology 58, 1939-1949.

306

307 Abraham, W.-R., Rohde, M., 2014. The Family Hyphomonadaceae, in: Rosenberg, E., DeLong, E.F., Lory, S., Stackebrandt, E., Thompson, F. (Eds.), The Prokaryotes. Springer Berlin Heidelberg, Berlin, Heidelberg, pp. 283-299.

Albers, S.-V., Jarrell, K.F., 2015. The archaellum: how archaea swim. Frontiers in Microbiology 6. doi:10.3389/fmicb.2015.00023

Alleon, J., Bernard, S., Le Guillou, C., Beyssac, O., Sugitani, K., Robert, F., 2018. Chemical nature of the 3.4 Ga Strelley Pool microfossils. Geochemical Perspectives Letters 37-42.

Baludikay, B.K., Storme, J.-Y., François, C., Baudet, D., Javaux, E.J., 2016. A diverse and exquisitely preserved organic-walled microfossil assemblage from the Meso-Neoproterozoic Mbuji-Mayi Supergroup (Democratic Republic of Congo) and implications for Proterozoic biostratigraphy. Precambrian Research 281, 166-184.

Beeby, M., Ferreira, J.L., Tripp, P., Albers, S.-V., Mitchell, D.R., 2020. Propulsive nanomachines: the convergent evolution of archaella, flagella, and cilia. FEMS Microbiology Reviews fuaa006.

Bergholtz, T., Daugbjerg, N., Moestrup, O., Fernandez-Tejedor, M., 2006. On the identity of karlodinium veneficum and description of karlodinium armiger sp. nov. (dinophyceae), based on light and electron microscopy, nuclear-encoded lsu rdna, and pigment composition. Journal of Phycology 42, 170-193.

Bernard, S., Beyssac, O., Benzerara, K., Findling, N., Tzvetkov, G., Brown, G.E., 2010. XANES, Raman and XRD study of anthracene-based cokes and saccharose-based chars submitted to high-temperature pyrolysis. Carbon 48, 2506-2516. 
Brasier, M., McLoughlin, N., Green, O., Wacey, D., 2006. A fresh look at the fossil evidence for early Archaean cellular life. Philosophical Transactions of the Royal Society B: Biological Sciences 361, 887-902.

Brasier, M.D., Green, O.R., Jephcoat, A.P., Kleppe, A.K., Van Kranendonk, M.J., Lindsay, J.F., Steele, A., Grassineau, N.V., 2002. Questioning the evidence for Earth's oldest fossils. Nature 416, 76-81.

Cosmidis, J., Templeton, A.S., 2016. Self-assembly of biomorphic carbon/sulfur microstructures in sulfidic environments. Nature Communications 7, 12812.

Craveiro, S.C., Moestrup, Ø., Daugbjerg, N., Calado, A.J., 2010. Ultrastructure and Large Subunit rDNA-Based Phylogeny of Sphaerodinium cracoviense, an Unusual Freshwater Dinoflagellate with a Novel Type of Eyespot: Sphaerodinium ultrastructure and phylogeny. Journal of Eukaryotic Microbiology 57, 568-585.

Curtis, P.D., 2017. Stalk formation of Brevundimonas and how it compares to Caulobacter crescentus. PLOS ONE 12, e0184063.

Delarue, F., Robert, F., Derenne, S., Tartèse, R., Jauvion, C., Bernard, S., Pont, S., GonzalezCano, A., Duhamel, R., Sugitani, K., 2020. Out of rock: A new look at the morphological and geochemical preservation of microfossils from the 3.46 Gyr-old Strelley Pool Formation. Precambrian Research 336, 105472.

Delarue, F., Robert, F., Sugitani, K., Tartèse, R., Duhamel, R., Derenne, S., 2017. Investigation of the Geochemical Preservation of ca. 3.0 Ga Permineralized and Encapsulated Microfossils by Nanoscale Secondary Ion Mass Spectrometry. Astrobiology 17, 1192-1202.

Deng, Y., Chen, C., Zhao, Z., Zhao, J., Jacq, A., Huang, X., Yang, Y., 2016. The RNA Chaperone Hfq Is Involved in Colony Morphology, Nutrient Utilization and Oxidative and Envelope Stress Response in Vibrio alginolyticus. PLOS ONE 11, e0163689. 
El Albani, A., Mangano, M.G., Buatois, L.A., Bengtson, S., Riboulleau, A., Bekker, A.,

352 Konhauser, K., Lyons, T., Rollion-Bard, C., Bankole, O., Lekele Baghekema, S.G., Meunier, 353 A., Trentesaux, A., Mazurier, A., Aubineau, J., Laforest, C., Fontaine, C., Recourt, P., Chi Fru, 354 E., Macchiarelli, R., Reynaud, J.Y., Gauthier-Lafaye, F., Canfield, D.E., 2019. Organism 355 motility in an oxygenated shallow-marine environment 2.1 billion years ago. Proceedings of 356 the National Academy of Sciences 116, 3431-3436.

357 Furuno, M., Atsumi, T., Yamada, T., Kojima, S., Nishioka, N., Kawagishi, I., Homma, M., 1997. Characterization of polar-flagellar-length mutants in Vibrio alginolyticus. Microbiology $143,1615-1621$.

Garcia-Ruiz, J.M., 2003. Self-Assembled Silica-Carbonate Structures and Detection of Ancient Microfossils. Science 302, 1194-1197.

House, C.H., Oehler, D.Z., Sugitani, K., Mimura, K., 2013. Carbon isotopic analyses of ca. 3.0 Ga microstructures imply planktonic autotrophs inhabited Earth's early oceans. Geology 41, $651-654$.

Jarrell, K.F., McBride, M.J., 2008. The surprisingly diverse ways that prokaryotes move. Nature Reviews Microbiology 6, 466-476.

Javaux, E.J., 2003. Recognizing and interpreting the fossils of early eukaryotes. Origins of Life and Evolution of the Biosphere 33, 75-94. Javaux, E.J., 2019. Challenges in evidencing the earliest traces of life. Nature 572, 451-460. Javaux, E.J., Marshall, C.P., Bekker, A., 2010. Organic-walled microfossils in 3.2-billion-year371 old shallow-marine siliciclastic deposits. Nature 463, 934-938.

372 Kanbe, M., Yagasaki, J., Zehner, S., Göttfert, M., Aizawa, S.-I., 2007. Characterization of Two 373 Sets of Subpolar Flagella in Bradyrhizobium japonicum. Journal of Bacteriology 189, 10831089. 
Khan, S., Scholey, J.M., 2018. Assembly, Functions and Evolution of Archaella, Flagella and Cilia. Current Biology 28, R278-R292.

Kinosita, Y., Uchida, N., Nakane, D., Nishizaka, T., 2016. Direct observation of rotation and steps of the archaellum in the swimming halophilic archaeon Halobacterium salinarum. Nature Microbiology 1, 16148.

Kouketsu, Y., Mizukami, T., Mori, H., Endo, S., Aoya, M., Hara, H., Nakamura, D., Wallis, S., 2014. A new approach to develop the Raman carbonaceous material geothermometer for lowgrade metamorphism using peak width. Island Arc 23, 33-50.

Kozawa, T., Sugitani, K., Oehler, D.Z., House, C.H., Saito, I., Watanabe, T., Gotoh, T., 2019. Early Archean planktonic mode of life: Implications from fluid dynamics of lenticular microfossils. Geobiology 17, 113-126.

Lahfid, A., Beyssac, O., Deville, E., Negro, F., Chopin, C., Goffé, B., 2010. Evolution of the Raman spectrum of carbonaceous material in low-grade metasediments of the Glarus Alps (Switzerland): RSCM in low-grade metasediments. Terra Nova 22, 354-360.

Le Guillou, C., Bernard, S., De la Pena, F., Le Brech, Y., 2018. XANES-Based Quantification of Carbon Functional Group Concentrations. Analytical Chemistry 90, 8379-8386.

Leander, B.S., Lax, G., Karnkowska, A., Simpson, A.G.B., 2017. Euglenida, in: Archibald, J.M., Simpson, A.G.B., Slamovits, C.H. (Eds.), Handbook of the Protists. Springer International Publishing, Cham, pp. 1047-1088.

Lepot, K., Williford, K.H., Ushikubo, T., Sugitani, K., Mimura, K., Spicuzza, M.J., Valley, J.W., 2013. Texture-specific isotopic compositions in 3.4Gyr old organic matter support selective preservation in cell-like structures. Geochimica et Cosmochimica Acta 112, 66-86.

Lim, H.C., Leaw, C.P., Tan, T.H., Kon, N.F., Yek, L.H., Hii, K.S., Teng, S.T., Razali, R.M., Usup, G., Iwataki, M., Lim, P.T., 2014. A bloom of Karlodinium australe (Gymnodiniales, 
399

400

401

402

403

404

405

406

407

408

409

410

411

412

413

414

415

416

417

418

419

420

421

422

423

Dinophyceae) associated with mass mortality of cage-cultured fishes in West Johor Strait, Malaysia. Harmful Algae 40, 51-62.

Loron, C.C., Rainbird, R.H., Turner, E.C., Greenman, J.W., Javaux, E.J., 2019. Organic-walled microfossils from the late Mesoproterozoic to early Neoproterozoic lower Shaler Supergroup (Arctic Canada): Diversity and biostratigraphic significance. Precambrian Research 321, 349374.

Miller, T.R., Hnilicka, K., Dziedzic, A., Desplats, P., Belas, R., 2004. Chemotaxis of Silicibacter sp. Strain TM1040 toward Dinoflagellate Products. Applied and Environmental Microbiology 70, 4692-4701.

Ng, S.Y.M., Zolghadr, B., Driessen, A.J.M., Albers, S.-V., Jarrell, K.F., 2008. Cell Surface Structures of Archaea. Journal of Bacteriology 190, 6039-6047.

Oehler, D.Z., Walsh, M.M., Sugitani, K., Liu, M.-C., House, C.H., 2017. Large and robust lenticular microorganisms on the young Earth. Precambrian Research 296, 112-119.

Pasteris, J.D., Wopenka, B., 2003. Necessary, but Not Sufficient: Raman Identification of Disordered Carbon as a Signature of Ancient Life. Astrobiology 3, 727-738.

Poindexter, J.S., Staley, J.T., 1996. Caulobacter and Asticcacaulis stalk bands as indicators of stalk age. Journal of bacteriology 178, 3939-3948.

Pyatibratov, M.G., Beznosov, S.N., Rachel, R., Tiktopulo, E.I., Surin, A.K., Syutkin, A.S., Fedorov, O.V., 2008. Alternative flagellar filament types in the haloarchaeon Haloarcula marismortui. Canadian Journal of Microbiology 54, 835-844.

Quintero, E.J., Busch, K., Weiner, R.M., 1998. Spatial and Temporal Deposition of Adhesive Extracellular Polysaccharide Capsule and Fimbriae by Hyphomonas Strain MHS-3. Applied and Environmental Microbiology 64, 1246-1255.

Schopf, J.W., Kudryavtsev, A.B., Agresti, D.G., Wdowiak, T.J., Czaja, A.D., 2002. LaserRaman imagery of Earth's earliest fossils. Nature 416, 73-76. 
Siano, R., Kooistra, W.H.C.F., Montresor, M., Zingone, A., 2009. Unarmoured and thin-walled dinoflagellates from the Gulf of Naples, with the description of Woloszynskia cincta sp. nov. (Dinophyceae, Suessiales). Phycologia 48, 44-65.

Southam, G., Kalmokoff, M.L., Jarrell, K.F., Koval, S.F., Beveridge, T.J., 1990. Isolation, characterization, and cellular insertion of the flagella from two strains of the archaebacterium Methanospirillum hungatei. Journal of Bacteriology 172, 3221-3228.

Sugimoto, S., Okuda, K., Miyakawa, R., Sato, M., Arita-Morioka, K., Chiba, A., Yamanaka, K., Ogura, T., Mizunoe, Y., Sato, C., 2016. Imaging of bacterial multicellular behaviour in biofilms in liquid by atmospheric scanning electron microscopy. Scientific Reports 6, 25889. Sugitani, K., Lepot, K., Nagaoka, T., Mimura, K., Van Kranendonk, M., Oehler, D.Z., Walter, M.R., 2010. Biogenicity of Morphologically Diverse Carbonaceous Microstructures from the ca. 3400 Ma Strelley Pool Formation, in the Pilbara Craton, Western Australia. Astrobiology $10,899-920$.

Sugitani, K., Mimura, K., Nagaoka, T., Lepot, K., Takeuchi, M., 2013. Microfossil assemblage from the 3400Ma Strelley Pool Formation in the Pilbara Craton, Western Australia: Results form a new locality. Precambrian Research 226, 59-74.

Sugitani, K., Mimura, K., Takeuchi, M., Lepot, K., Ito, S., Javaux, E.J., 2015. Early evolution of large micro-organisms with cytological complexity revealed by microanalyses of $3.4 \mathrm{Ga}$ organic-walled microfossils. Geobiology 13, 507-521.

Vasilyeva, L.V., Omelchenko, M.V., Berestovskaya, Y.Y., Lysenko, A.M., Abraham, W.-R., Dedysh, S.N., Zavarzin, G.A., 2006. Asticcacaulis benevestitus sp. nov., a psychrotolerant, dimorphic, prosthecate bacterium from tundra wetland soil. International Journal of Systematic and Evolutionary Microbiology 56, 2083-2088. 
Wacey, D., Kilburn, M.R., Saunders, M., Cliff, J., Brasier, M.D., 2011. Microfossils of sulphurmetabolizing cells in 3.4-billion-year-old rocks of Western Australia. Nature Geoscience 4, $698-702$.

Wacey, D., Saunders, M., Kong, C., Brasier, A., Brasier, M., 2016. 3.46 Ga Apex chert 'microfossils' reinterpreted as mineral artefacts produced during phyllosilicate exfoliation. Gondwana Research 36, 296-313.

Wagner, J.K., Setayeshgar, S., Sharon, L.A., Reilly, J.P., Brun, Y.V., 2006. A nutrient uptake role for bacterial cell envelope extensions. Proceedings of the National Academy of Sciences $103,11772-11777$.

Wang, H., Lu, D., Huang, H., Göbel, J., Dai, X., Xia, P., 2011. First observation of Karlodinium veneficum from the East China Sea and the coastal waters of Germany. Acta Oceanologica Sinica 30, 112-121.

Wang, Y., Chen, Y., Lavin, C., Gretz, M.R., 2000. Extracellular matrix assembly in diatoms (Bacillariophyceae). iv. ultrastructure of Achnanthes longipes and Cymbella cistula as revealed by high-pressure freezing/freeze substituton and cryo-field emission scanning electron microscopy. Journal of Phycology 36, 367-378.

Westall, F., de Ronde, C.E.J., Southam, G., Grassineau, N., Colas, M., Cockell, C., Lammer, H., 2006. Implications of a 3.472-3.333 Gyr-old subaerial microbial mat from the Barberton greenstone belt, South Africa for the UV environmental conditions on the early Earth. Philosophical Transactions of the Royal Society B: Biological Sciences 361, 1857-1876.

Wustman, B.A., Gretz, M.R., Hoagland, K.D., 1997. Extracellular Matrix Assembly in Diatoms (Bacillariophyceae) (I. A Model of Adhesives Based on Chemical Characterization and Localization of Polysaccharides from the Marine Diatom Achnanthes longipes and Other Diatoms). Plant Physiology 113, 1059-1069. 
1 Chemical degradation of thermally altered silicified organic matter during acid

2 maceration: a case study from the Lower Devonian Rhynie chert

3

4 Frédéric Delarue ${ }^{\mathrm{a}^{*}}$, Thanh Thuy Nguyen Tu ${ }^{\mathrm{a}}$, Rémi Duhamel ${ }^{\mathrm{b}}$, Céline Paris ${ }^{\mathrm{c}}$, François

5 Baudin $^{\mathrm{d}}$

6

7 a Sorbonne Université, CNRS, EPHE, PSL, UMR 7619 METIS, 4 place Jussieu, F-75005

8 Paris, France

$9 \quad{ }^{\mathrm{b}}$ Muséum National d'Histoire Naturelle, Sorbonne Université, UMR 7590, IRD, IMPMC, F75005 Paris, France

' Sorbonne Université, CNRS, UMR 8233 MONARIS, 75005, 4 place Jussieu, F-75005 Paris,

Paris, France

${ }^{\mathrm{d}}$ Sorbonne Université, CNRS, UMR 7193 ISTeP, 4 place Jussieu, F-75005 Paris, France 


\section{ABSTRACT}

The effect of standard acid maceration on organic matter (OM) from ancient silicified sediments remains undocumented. Early silicification favours preservation of organic moieties against thermal alteration over time. In this study, we investigated the effects of acid maceration on the structure of OM isolated from the Lower Devonian Rhynie chert. The structure of OM was investigated by combining Rock-Eval pyrolysis and Raman spectroscopy. Besides a loss of thermolabile organic matter owing to solvent extraction, Rock-Eval pyrolysis showed that standard acid maceration also causes a loss of C-H emissions at high pyrolysis temperature $\left(>500^{\circ} \mathrm{C}\right)$. The standard acid maceration procedure was also associated with the disappearance of the D4 and D5 Raman spectrum shoulders assigned to $\mathrm{C}-\mathrm{H}$ bonds in aliphatics and bitumens, respectively, entrapped in the macromolecular network. Taken together, Rock-Eval pyrolysis and Raman spectroscopy indicate that standard acid maceration can lead to the chemical degradation of syngenetic hydro-carbonaceous moieties of OM isolated from ancient silicified and thermally altered sediments. In sediments having experienced early silicification, which hampers bitumen migration and favours pyrobitumen formation, we suggest that novel in situ molecular analytical techniques are required to provide a thorough examination of the syngenetic molecular content independent of the soluble/insoluble operational definition.

\section{Introduction}

The chemical composition of ancient organic matter $(\mathrm{OM})$ attests to turning points in the evolution of life during the history of the Earth (Summons et al., 1988; Edwards et al., 1997; Love et al., 2008; Duda et al., 2016; Nguyen et al., 2019; Love et al., 2020). However, investigating the structural and chemical compositions of ancient $\mathrm{OM}$ is still a challenging issue as thermal alteration during geological times results in losses of pristine molecular and 
elemental content. Since ancient sediments and metasediments are generally depleted in OM, isolation procedures have typically been employed before applying analytical techniques to investigate the chemical composition of ancient OM, notably at the molecular scale.

Historically, in the field of organic geochemistry, isolation of organic-insoluble and mineralfree $\mathrm{OM}$ is performed through a standard acid maceration procedure involving maceration followed by successive organic solvent extractions (e.g., dichloromethane [DCM] and methanol $[\mathrm{MeOH}]$ ) and demineralisation with acid (e.g., hydrochloric $[\mathrm{HCl}]$ and hydrofluoric $[\mathrm{HF}])$. This physical and chemical maceration procedure (HMM) yields kerogen, which is defined as insoluble macromolecular OM (Durand, 1980; Vandenbroucke and Largeau, 2007). Several investigations have suggested that acid maceration does not significantly modify the structure of kerogens from ancient rocks (Larsen et al., 1989; Vandenbroucke and Largeau, 2007; Aboulkas and El Harfi, 2009). However, there is contrasting evidence that acid maceration of coals can lead to either a rise in carbon structural order (Zhang et al., 2016) or a decrease in hydrocarbon content (Tekely et al., 1987). Moreover, Kebukawa et al. (2019) demonstrated the contrasting effects of acid maceration by comparing the chemical structure of bulk chondrites to their corresponding insoluble OM fractions. Insoluble OM from type 3 chondrite was depleted in aliphatic moieties in comparison to the bulk type 3 chondrite starting material. However, the effect of acid maceration varied among the different chondrite groups studied (Kebukawa et al., 2019). Thus, according to current literature, it therefore seems that the chemical stability of thermally altered OM to standard acid maceration cannot simply be assumed.

Among ancient sedimentary rocks, silicified sediments are of interest as they are essential geological archives of biological evolution throughout Earth's history. However, there is often very little OM remaining in these sediments and acid maceration procedures are required to concentrate it before studying its molecular content. Occurring prior to cell lysis 
and early degradation of organic matter, rapid silicification leads to a closed chemical system by reducing sediment porosity (Boyce et al., 2002; Ledevin et al., 2014), which favours preservation of organic remnants against thermal alteration (Alleon et al., 2016). Using geochemical micrometre-scale analysis tools, it was demonstrated that some silicified Precambrian organic-walled microfossils are composed of significant amounts of carbonyl, phenolic, carboxylic, hydroxyl, and amide functional groups, despite being subjected to peak temperatures of up to $300{ }^{\circ} \mathrm{C}$ (Alleon et al., 2016). However, standard acid maceration procedures applied to ancient silicified sediments have the potential to degrade syngenetic OM through solvent extraction and acid hydrolysis of bitumens and chemically labile organic moieties, respectively. Such degradation, if it occurs, implies that a substantial amount of the initial molecular content depicting the evolution of life, past environmental conditions, and/or thermal maturation may be lost in the process. Further investigations on the effect of standard acid maceration on the chemical structure of ancient thermally altered silicified OM are therefore required.

Our aim in this study was to investigate the effect of the standard acid maceration procedure on the chemical structure of ancient silicified OM. We selected the iconic Lower Devonian Rhynie chert, the earliest preserved terrestrial ecosystem owing to a rapid and complete silicification through siliceous hot-spring deposits (Trewin, 2003; Preston and Genge, 2010). Despite the exceptional preservation of fossil plants, fungi, insects, and other organisms, the overall organic carbon content of Rhynie chert is very low (Summons et al., 1996). It therefore typically requires acid maceration to access the molecular signature(s). The Rhynie chert therefore constitutes a case study to evaluate the impact of standard acid maceration on the chemical structure of ancient thermally altered silicified OM. To this end, OM was isolated according to two acid maceration procedures: (1) a high-manipulation maceration (HMM), which followed the standard treatments generally applied to geological 
samples, and (2) a low-manipulation maceration (LMM), which minimized chemical degradation by avoiding organic solvents and $\mathrm{HCl}$. Rock-Eval pyrolysis and Raman spectroscopy were used to assess the chemical structure of the OM isolated by each procedure. Comparison of the so-obtained chemical structures allowed us to estimate the minimum amount of chemical degradation imparted by HMM maceration.

\section{Material and methods}

\subsection{The Rhynie chert}

Situated in Aberdeenshire (Scotland), the Rhynie chert is a Konservat-Lagerstätte. It is hosted by the Dryden Flags Formation, which is characterised by a succession of Lower Devonian sedimentary and volcanic rocks (Rice et al., 2002). Pragian-earliest Emsian in age (407.1 $\pm 2.2 \mathrm{Ma}$; Mark et al., 2011), the Rhynie chert is composed primarily of microcrystalline silica and was deposited as siliceous sinter from subaerial hot springs systems (Rice et al., 1995).

\subsection{High- and low-manipulation maceration procedures}

HMM and LMM procedures were performed on similar portions of the same rock sample. HMM was performed on $\sim 30 \mathrm{~g}$ of crushed rock. Solvent extraction was first performed on rock powder using a mixture of DCM and $\mathrm{MeOH}(2: 1 ; \mathrm{v}: \mathrm{v})$. Carbonates were then removed at room temperature using $\mathrm{HCl}(37 \%$; reagent grade) to minimise the formation of fluorides during subsequent $\mathrm{HF} / \mathrm{HCl}$ maceration. Samples were then centrifuged and washed with ultrapure water until reaching neutrality. Concentration of OM was achieved through acid maceration at room temperature in a mixture of HF $(40 \%$, reagent grade $)$ and $\mathrm{HCl}(2: 1, \mathrm{v} / \mathrm{v}$; reagent grade). Samples were centrifuged and washed with ultrapure water to reach neutrality. Finally, $\mathrm{HCl}\left(37 \%\right.$; reagent grade) at $60{ }^{\circ} \mathrm{C}(24 \mathrm{~h})$ was used to degrade 
neoformed fluorides. After an additional step of solvent extraction using a mixture of DCM and $\mathrm{MeOH}(2: 1, \mathrm{v} / \mathrm{v})$, the isolated $\mathrm{OM}$ was again centrifuged/washed with ultrapure water until reaching neutrality. Samples were then air-dried at $60{ }^{\circ} \mathrm{C}$ after final rinsing in acetone. Hereafter, OM isolated by the HMM procedure is referred to as OHMM.

LMM was performed by first fragmenting $\sim 30 \mathrm{~g}$ of rock samples into $\sim 3 \mathrm{~g}$ rock chips. Rock chips were cleaned using ultrapure water and a mixture of DCM and $\mathrm{MeOH}(2: 1, \mathrm{v} / \mathrm{v})$ and were then placed directly in a Teflon vessel filled with HF (40\%, reagent grade) at room temperature. After $48 \mathrm{~h}$, successive centrifugation and rinsing steps using ultrapure water were performed until reaching neutrality. Samples were then air-dried at $60{ }^{\circ} \mathrm{C}$. Hereafter, OM isolated by the LMM procedure is referred to as OLMM.

\subsection{Rock-Eval pyrolysis}

OHMM and OLMM were analysed using Rock-Eval 6 (Vinci Technologies) following the standard pyrolysis protocol described in Behar et al. (2001). Performed in a $\mathrm{N}_{2}$ atmosphere, Rock-Eval pyrolysis comprises two steps: an isothermal phase held for 3 minutes followed by a rise in pyrolysis temperature from 300 to $650{ }^{\circ} \mathrm{C}$ at a rate of $25^{\circ} \mathrm{C} / \mathrm{min}$. After pyrolysis, the residual material was then heated from $300{ }^{\circ} \mathrm{C}$ to $850{ }^{\circ} \mathrm{C}$ under purified air in an oxidation oven in order to calculate total organic carbon (TOC) value (see Behar et al., 2001 for further details about calculation procedure). Released hydrocarbons (HC) were continuously quantified by a flame ionisation detector (S1 and S2, for the first and second pyrolysis steps, respectively, in $\mathrm{mg} \mathrm{HC} / \mathrm{g}$ of sample) while released $\mathrm{CO}$ and $\mathrm{CO}_{2}$ were continuously and simultaneously monitored by infrared detectors during both pyrolysis $\left(\mathrm{S} 3 \mathrm{CO}\right.$ and $\left.\mathrm{S}_{3} \mathrm{CO}_{2}\right)$ and combustion $\left(\mathrm{S} 4 \mathrm{CO}\right.$ and $\left.\mathrm{S}_{4} \mathrm{CO}_{2}\right)$. Quantification of the amount of effluents led to the determination of the TOC (wt\%), of the Hydrogen Index (HI, defined as $\mathrm{S} 2 \times 100 / \mathrm{TOC}$, in $\mathrm{mg} \mathrm{HC} / \mathrm{g}$ of TOC) and of the Oxygen Index (OI; defined as S3×100/TOC, in 
$\mathrm{mg} \mathrm{CO} / \mathrm{g}$ of TOC). The pyrolysis temperature associated with the maximum release of hydrocarbons, called "TpkS2", was also determined.

\subsection{Raman spectroscopy}

Raman spectroscopy analysis was performed using a Renishaw inVia microspectrometer equipped with a $532 \mathrm{~nm}$ argon laser. The spectrometer was first calibrated using a silicon standard before each session. For each sample analysis, the laser was focused using a Leica microscope with a $\times 50$ objective and the spectra were recorded in the $1000-1900 \mathrm{~cm}^{-1}$ first order spectral window including the defect (D) and graphite $(G)$ peaks (Fig. 1). The laser power at the sample surface was kept below $1 \mathrm{~mW}$ to prevent thermal alteration of isolated OM (Everall et al., 1991). Spectra acquisition was achieved after two iterations using a time exposure of $40 \mathrm{~s}$. After linear correction of the baseline between 1000 and $1900 \mathrm{~cm}^{-1}$ and spectra normalization, we identified Raman peaks according to the nomenclature defined in Romero-Sarmiento et al. (2014).

The heights of the sub-bands D1 $\left(\sim 1365 \mathrm{~cm}^{-1}\right)$, D4 $\left(\sim 1285 \mathrm{~cm}^{-1}\right)$, D5 $\left(\sim 1445 \mathrm{~cm}^{-1}\right)$ and $\mathrm{G}+\mathrm{D} 2\left(\sim 1600 \mathrm{~cm}^{-1}\right.$; Fig. 1) were then determined to compute the $\mathrm{I}_{\mathrm{D} 1} / \mathrm{I}_{\mathrm{G}+\mathrm{D} 2}, \mathrm{I}_{\mathrm{D} 4} / \mathrm{I}_{\mathrm{G}+\mathrm{D} 2}$ and $\mathrm{I}_{\mathrm{D} 5} / \mathrm{I}_{\mathrm{G}+\mathrm{D} 2}$, ratios. Slopes $\alpha_{\mathrm{D} 4}$ (determined between 1265 and $1300 \mathrm{~cm}^{-1}$ Raman shift) and $\alpha_{\mathrm{D} 5}$ (determined between 1415 and $1445 \mathrm{~cm}^{-1}$ Raman shift) were determined to geometrically evaluate the expression of D4 and D5 shoulders on the D band.

\section{Results and discussion}

The TOC of OHMM and OLMM samples was measured to determine the efficiency of rock mineralization through HMM and LMM, respectively. The TOC in all OHMM and OLMM samples was low (25.4\% and $27.5 \%$ respectively; Table 1$)$ suggesting that the preservation and/or neoformation of substantial mineral content had occurred during both 
procedures. The OI was approximately $15 \mathrm{mg}$ and $59 \mathrm{mg} \mathrm{CO} / \mathrm{g}$ TOC in OHMM and OLMM, respectively (Table 1). The higher OI in OLMM is partially explained by the higher level of $\mathrm{CO}_{2}$ emissions during the first isothermal step, showing that they are mostly related to desorbable OM (Fig. 2). Such a result is in line with previous investigations on coals suggesting that acid maceration can lead to a rise in oxygen content resulting possibly from the neoformation of carboxylic groups replacing carboxylate through ion exchange (Larsen et al., 1989). Higher levels of $\mathrm{CO}_{2}$ emissions were also recorded for OLMM during the rise in pyrolysis temperature from 300 to $650{ }^{\circ} \mathrm{C}$ (Fig. 2). In this pyrolysis temperature range, $\mathrm{CO}_{2}$ emissions appeared to be independent of hydrocarbon emissions suggesting that they do not correspond to the thermal cracking of the macromolecular network.

OHMM and OLMM isolated from the Rhynie chert were characterised by a TpkS2 of $481{ }^{\circ} \mathrm{C}$ and $504{ }^{\circ} \mathrm{C}$, respectively (Table 1). In every type of kerogen, these pyrolysis temperatures are commonly assigned to OM that has been subjected to high thermal alteration. Consistent with high TpkS2 values, pyrolysis of OHMM and of OLMM released low amounts of $\mathrm{HC}$ as evidenced by $\mathrm{HI}$ of $46 \mathrm{HC} / \mathrm{g}$ TOC and $68 \mathrm{mg} \mathrm{HC} / \mathrm{g}$ TOC, respectively. Together, high TpkS2 and low HI imply that OM from the Rhynie chert falls at the transition between the oil and gas windows registered by TpkS2 ranging between $470{ }^{\circ} \mathrm{C}$ and $505{ }^{\circ} \mathrm{C}$ in analogous Type III kerogens (Espitalié et al., 1986). Hydrocarbon release during Rock-Eval pyrolysis was higher in OLMM than in OHMM (Table 1). The S1 value for OLMM was about $320 \%$ higher than for OHMM (Table 1), which suggests that thermolabile OM was more abundant in OLMM than in OHMM. This is consistent with the fact that OLMM was not subjected to organic solvent extractions, which have been shown to dramatically reduce S1 values (Delvaux et al., 1990). Between 300 and $350{ }^{\circ} \mathrm{C}$, no release of hydrocarbons was observed suggesting a virtual absence of residual heavy oil and/or of pyrobitumen in both OHMM and OLMM (Fig. 2; Clementz, 1979; Sanei et al., 2015). The S2 curves for OHMM 
and OLMM differ at high pyrolysis temperature $\left(>500^{\circ} \mathrm{C}\right)$, at which point a broad shoulder is only observed in OLMM (Fig. 2). The occurrence of this thermorecalcitrant OM in OLMM mostly explains its higher HI, in the absence of solvent extractions and/or hydrochloric acid hydrolysis (Table 1). In turn, this suggests that standard acid maceration can lead to a modification of the macromolecular chemical structure in this ancient silicified OM by promoting a loss of hydrocarbonaceous moieties.

Determined on 15 random targets in both OHMM and OLMM, Raman spectra exhibited two broad D and G+D2 bands at around $1365 \mathrm{~cm}^{-1}$ and $1600 \mathrm{~cm}^{-1}$ in each preparation (Fig. 1). The D band presents a complex structure resulting from the presence of several sub-bands including here, the D4, D1, and D5 bands. In addition to the contribution of amorphous carbon, the D band is dominated by the D1 sub-band corresponding to the breathing mode of the $\mathrm{sp}^{2}$ aromatic ring within polyaromatic clusters and is attributed to defects in these aromatic structures (Ferrari and Robertson, 2000). The D2 band corresponds to defects in aromatic structure but in contrast to the D1 band, does not include amorphous carbon. A distinct D2 peak (usually centered at about $1620 \mathrm{~cm}^{-1}$ ) is mainly observed in highly mature OM (Kouketsu et al. 2014) and is not observed in OM studied here. Therefore, the $\mathrm{G}+\mathrm{D} 2$ band is mostly related to the $\mathrm{G}$ band corresponding to in-plane $\mathrm{C}-\mathrm{C}$ bond stretching in polyaromatic layers from thermally altered materials (Marshall and Marshall, 2014). As the height of the $\mathrm{D} 1$ band increases with temperature, the $\mathrm{I}_{\mathrm{D} 1} / \mathrm{I}_{\mathrm{G}+\mathrm{D} 2}$ ratio is often used to probe the structural order of OM in the course of carbonization (Table 2; Wopenka and Pasteris, 1993; Quirico et al., 2005; Kouketsu et al., 2014; Delarue et al., 2016). In this study, OHMM and OLMM are characterized by $\mathrm{I}_{\mathrm{D} 1} / \mathrm{I}_{\mathrm{G}+\mathrm{D} 2}$ ratios of $0.58 \pm 0.02$ and $0.52 \pm 0.02$, respectively (Table 2). This result would imply a higher carbon structural order in OHMM compared to OLMM, which is in agreement with previous findings indicating that standard acid maceration can yield a rise in carbon structural order (Zhang et al., 2016). 
The D band also exhibits two shoulders corresponding to the D4 $\left(1285 \mathrm{~cm}^{-1}\right)$ and D5

$218\left(1445 \mathrm{~cm}^{-1}\right)$ bands (Fig. 1). The D4 peak is generally assigned to $\mathrm{C}-\mathrm{H}$ bonds in aliphatics as

$219 \mathrm{C}-\mathrm{H}$ in aromatics does not seem to directly contribute to the D4 region (Ferralis et al., 2016).

The D5 band indicates the presence of hydrocarbons trapped within the organic porosity and has been detected in a few oil and gas shale samples (Romero-Sarmiento et al., 2014;

Rouzaud et al., 2015). In the current study, $\alpha_{\mathrm{D} 4}$ and $\alpha_{\mathrm{D} 5}$ slopes in Raman spectra were lower in

OLMM than in OHMM, consistent with the more pronounced D4 and D5 shoulders in the

Raman line of OLMM (Fig. 1; Table 2). However, the more pronounced D4 and D5 shoulders

in OLMM were not associated with higher $\mathrm{I}_{\mathrm{D} 4} / \mathrm{I}_{\mathrm{G}+\mathrm{D} 2}$ and $\mathrm{I}_{\mathrm{D} 5} / \mathrm{I}_{\mathrm{G}+\mathrm{D} 2}$ ratios (Table 2). This could

be explained by the higher carbon structural order in OHMM implying a bias in the

determination of $\mathrm{I}_{\mathrm{D} 4} / \mathrm{I}_{\mathrm{G}+\mathrm{D} 2}$ and $\mathrm{I}_{\mathrm{D} 5} / \mathrm{I}_{\mathrm{G}+\mathrm{D} 2}$ ratios. The occurrence of more pronounced D4 and D5 shoulders in OLMM indicate that OLMM is indeed enriched in hydrocarbonaceous moieties, due to the $\mathrm{C}-\mathrm{H}$ bonds in aliphatics and other entrapped hydrocarbons, relative to OHMM. The presence of entrapped hydrocarbons in the macromolecular network of OLMM likely explains the broad shoulder cracking at high temperature $\left(>500{ }^{\circ} \mathrm{C}\right)$ as revealed by Rock-Eval pyrolysis (Fig. 2). Both Raman spectroscopy and Rock-Eval pyrolysis suggest that standard acid maceration results in a loss of hydrocarbons in OM isolated from the Rhynie chert. As LMM does not involve the organic solvent extraction used in HMM, part of this hydrocarbon loss is likely due to solvent-extractible OM, which is reflected by the respective S1 values. In contrast to OHMM, OLMM did not involve extraction with $\mathrm{HCl}$, which when mixed with $\mathrm{HF}$

237 has been demonstrated to favour hydrolysis leading to a loss of aliphatic $\mathrm{CH}$ and/or $\mathrm{CH}_{2}$

238 functional groups in coal (Tekely et al., 1987). Even though our experimental design did not 239 allow us to test the singular effect of $\mathrm{HCl}$ hydrolysis, such an effect can be hypothesized to partly explain the loss in aliphatic moieties with HMM treatment. 
Although the Raman spectroscopy results support the notion that hydrocarbons are lost

during HMM, it does not directly allow the extent of this loss to be determined. Following the relationship between $\mathrm{H} / \mathrm{C}$ and $\mathrm{HI}$ (Espitalié et al., 1977), we determined that $\mathrm{H} / \mathrm{C}$ atomic ratios were 0.53 and 0.57 in OHMM and OLMM, respectively (Table 1). Standard acid maceration therefore led to a reduction of at least about $7-8 \%$ of the hydrocarbon content of Rhynie OM. We use "at least" because chemical degradation of hydrocarbons occurring during the isolation of OLMM cannot be straightforwardly excluded. To evaluate this point, Raman spectra were also acquired on in situ OM from thin sections of Rhynie chert

(Supplementary information). These in situ Raman spectra were acquired with another Raman spectroscope and on polished thin sections, which can modify the apparent carbon structural order by yielding an increase in the D band (Ammar et al., 2011; Maslova et al., 2012). These issues therefore prevent a straightforward comparison between Raman-derived ratios from in situ OM and from OLMM/OHMM. Nonetheless, the $\alpha_{\mathrm{D} 4}$ and $\alpha_{\mathrm{D} 5}$ parameters are independent of the height of the D band and can be used to track a potential effect of LMM procedure. In situ OM presents a mean $\alpha_{D 4}$ and $\alpha_{D 5}$ of about $31 \pm 4$ and $-24 \pm 23$, respectively $(n=10)$, indicating more pronounced D4 and D5 shoulders in the in situ OM compared to OLMM (Supplementary information). This suggests that simple treatment with HF and water also led to a slight loss in aliphatic content. In addition to these hydrocarbon losses related to acid maceration procedures, the estimated $7-8 \%$ loss in hydrocarbons can also be considered as minimum estimation because of thermolabile hydrocarbons (S1 parameter), which are not taken into account in the calculation of HI and were more abundant in OLMM than in OHMM.

Thermolabile hydrocarbons are tightly linked to soluble OM (Delvaux et al., 1990). However, this soluble OM in ancient sediments is often ignored because its syngeneity can be difficult to prove due to the potential for post-deposit contamination (Brocks et al., 2003a, 
2003b; Derenne et al., 2008). However, silicified sediments can be seen as unconventional dual source/reservoir rocks. Indeed, rapid silicification drastically reduces porosity leading to a closed chemical system (Boyce et al., 2002; Ledevin et al., 2014). In such source/reservoir rocks, migration of bitumens was very restricted implying that bitumens and/or pyrobitumens coexisted in close proximity with residual kerogens (Vandenbroucke and Largeau, 2007).

Hence, in ancient silicified sediments, bitumens and pyrobitumens can be considered syngenetic.

$$
\text { In contrast to soluble OM, insoluble OM is often considered less prone to late }
$$
contamination (Derenne et al., 2008). Involving no chemical treatment or low-manipulation procedures, numerous studies have investigated the molecular structure of $\mathrm{OM}-$ at the scale of plant fossils - to assess the effects of fossilization or to depict plant evolution and affinities (Ewbank et al., 1996; Edwards et al., 1997; Abbott et al., 1998; Czaja et al., 2009; Quijada et al., 2016). Because a large proportion of the hydrocarbon content of these samples is preserved, these investigations minimized secondary hydrothermal and endolithic contaminations - which can also yield insoluble OM - by studying insoluble OM directly from plant fossils. To avoid contamination and to optimize the study of syngenetic hydrocarbons that can be degraded in the course of acid maceration, the development of in situ molecular micrometre-scale analyses techniques (e.g., time-of-flight secondary ion mass spectrometry and laser micropyrolysis) are of interest. Such techniques have the potential to directly probe the molecular structure of organic fossils independent of the soluble/insoluble operational definition. In addition to insightfully assessing chemical heterogeneity within macrofossils (Boyce et al., 2002; Abbott et al., 2018), in situ molecular micrometre-scale analyses also offers the possibility to study the molecular composition of micrometric to submicrometric diffuse particulate OM (Stout, 1993; Greenwood et al., 2001; Yoshioka and 
Takeda, 2004; Silva et al., 2016). This includes remnants of microorganisms, such as organicwalled microfossils, which are essential organic components of the early geological record. In the specific context of silicified rocks - where silicification prevented migration of bitumens and favoured formation of pyrobitumen in the close vicinity of the residual kerogen - the use of in situ molecular micrometre-scale analyses offers promise in the investigation of the molecular composition of early life found within Archean silicified sediments. Indeed, the emergence of micrometre-scale in situ analyses have provided compelling evidence supporting an unexpected and wide chemical heterogeneity among Archean putative organicwalled microfossils (Delarue et al., 2017, 2020; Hickman-Lewis et al., 2020). Overlooked by bulk extraction approaches, this chemical heterogeneity defines a chemically-well preserved end product among the earliest traces of life. Therefore, the precise study of such geological archives requires further development of in situ molecular micrometre-scale analyses Such techniques may pave the way to document biological and abiotic processes and affinities of the earliest putative remnants of life by: (i) focussing on chemically well preserved specimens, (ii) without the use of chemical extraction and maceration techniques, which can degrade aliphatic moieties preserved in sediments subjected to early and prompt silicification.

\section{Conclusions}

In this study, we investigated the impact of standard acid maceration on the chemical structure of silicified OM from the Lower Devonian Rhynie chert. Using Rock-Eval pyrolysis and Raman spectroscopy, we assessed the chemical structure of OM isolated by two different physical and chemical manipulation procedures. Results from Rock-Eval pyrolysis and Raman spectroscopy converged to demonstrate that the standard procedure of OM isolation led to a significant and substantial degradation of hydrocarbons. These chemical alterations indicate that a significant amount of molecular content is lost as a result of standard acid 
maceration procedures, thus preventing a thorough examination of the molecular content of organic remnants in thermally altered silicified sediments.

\section{Acknowledgements}

Authors are grateful to Andrew Ross (Department of Natural Sciences, National Museum of Scotland, Edinburgh) for providing the Rhynie chert sample. We also thank F. Savignac (ISTeP) for Rock-Eval pyrolysis and O. Belhadj (CRCC) for Raman spectroscopy. We also acknowledge K. Liitschwager for proofreading the English writing of this manuscript. J.K. Volkman, G.D. Abbott, anonymous reviewers and C.K. Boyce are acknowledged for their constructive comments on the former versions of the manuscript.

\section{References}

Abbott, G.D., Ewbank, G., Edwards, D., Wang, G.-Y., 1998. Molecular characterization of some enigmatic Lower Devonian fossils. Geochimica et Cosmochimica Acta 62, $1407-1418$.

Abbott, G.D., Fletcher, I.W., Tardio, S., Hack, E., 2018. Exploring the geochemical distribution of organic carbon in early land plants: a novel approach. Philosophical Transactions of the Royal Society B: Biological Sciences 373, 20160499.

Aboulkas, A., El Harfi, K., 2009. Effects of acid treatments on Moroccan Tarfaya oil shale and pyrolysis of oil shale and their kerogen. Journal of Fuel Chemistry and Technology 37, 659-667.

Alleon, J., Bernard, S., Le Guillou, C., Daval, D., Skouri-Panet, F., Pont, S., Delbes, L., Robert, F., 2016. Early entombment within silica minimizes the molecular degradation of microorganisms during advanced diagenesis. Chemical Geology 437, 98-108.

Ammar, M.R., Charon, E., Rouzaud, J.-N., Aleon, J., Guimbretière, G., Simon, P., 2011. On a 
reliable structural characterization of polished carbons in meteorites by Raman microspectroscopy. Spectroscopy Letters 44, 535-538.

Behar, F., Beaumont, V., De B. Penteado, H.L., 2001. Rock-Eval 6 Technology: Performances and Developments. Oil \& Gas Science and Technology 56, 111-134.

Boyce, C.K., Cody, G.D., Feser, M., Jacobsen, C., Knoll, A.H., Wirick, S., 2002. Organic chemical differentiation within fossil plant cell walls detected with X-ray spectromicroscopy. Geology 30, 1039-1042.

Brocks, J.J., Buick, R., Logan, G.A., Summons, R.E., 2003a. Composition and syngeneity of molecular fossils from the 2.78 to 2.45 billion-year-old Mount Bruce Supergroup, Pilbara Craton, Western Australia. Geochimica et Cosmochimica Acta 67, 4289-4319.

Brocks, J.J., Love, G.D., Snape, C.E., Logan, G.A., Summons, R.E., Buick, R., 2003b. Release of bound aromatic hydrocarbons from late Archean and Mesoproterozoic kerogens via hydropyrolysis. Geochimica et Cosmochimica Acta 67, 1521-1530.

Czaja, A.D., Kudryavtsev, A.B., Cody, G.D., Schopf, J.W., 2009. Characterization of permineralized kerogen from an Eocene fossil fern. Organic Geochemistry 40, 353364.

Clementz, D., 1979. Effect of oil and bitumen saturation on source-rock pyrolysis: Geologic notes. AAPG Bulletin 63. doi:10.1306/2F918919-16CE-11D7-8645000102C1865D

Delarue, F., Robert, F., Derenne, S., Tartèse, R., Jauvion, C., Bernard, S., Pont, S., GonzalezCano, A., Duhamel, R., Sugitani, K., 2020. Out of rock: A new look at the morphological and geochemical preservation of microfossils from the 3.46 Gyr-old Strelley Pool Formation. Precambrian Research 336, 105472.

Delarue, F., Robert, F., Sugitani, K., Tartèse, R., Duhamel, R., Derenne, S., 2017. Investigation of the geochemical preservation of ca. $3.0 \mathrm{Ga}$ permineralized and encapsulated microfossils by nanoscale secondary ion mass spectrometry. 
Astrobiology 17, 1192-1202.

366 Delarue, F., Rouzaud, J.-N., Derenne, S., Bourbin, M., Westall, F., Kremer, B., Sugitani, K., Deldicque, D., Robert, F., 2016. The Raman-derived carbonization continuum: A tool to select the best preserved molecular structures in Archean kerogens. Astrobiology $16,407-417$.

Delvaux, D., Martin, H., Leplat, P., Paulet, J., 1990. Comparative Rock-Eval pyrolysis as an improved tool for sedimentary organic matter analysis. Organic Geochemistry 16, $1221-1229$.

Derenne, S., Robert, F., Skrzypczak-Bonduelle, A., Gourier, D., Binet, L., Rouzaud, J.-N., 2008. Molecular evidence for life in the 3.5 billion year old Warrawoona chert. Earth and Planetary Science Letters 272, 476-480.

Duda, J.-P., Thiel, V., Reitner, J., Grazhdankin, D., 2016. Opening up a window into ecosystems with Ediacara-type organisms: preservation of molecular fossils in the Khatyspyt Lagerstätte (Arctic Siberia). PalZ 90, 659-671.

Durand, B. (Ed.), 1980. Kerogen, Insoluble Organic Matter from Sedimentary Rocks. Editions Technip 27, Paris, pp. 519.

Edwards, D., Ewbank, G., Abbott, G.D., 1997. Flash pyrolysis of the outer cortical tissues in Lower Devonian Psilophyton dawsonii. Botanical Journal of the Linnean Society 124, $345-360$.

Espitalié, J., 1986. Use of Tmax as a maturation index for different types of organic matter: comparison with vitrinite reflectance. Collection colloques et séminaires - Institut français du pétrole pp. 475-496.

Espitalié, J., Laporte, J.L., Madec, M., Marquis, F., Leplat, P., Paulet, J., Boutefeu, A., 1977. Méthode rapide de caractérisation des roches mètres, de leur potentiel pétrolier et de leur degré d'évolution. Revue de l'Institut Français du Pétrole 32, 23-42. 
Everall, N.J., Lumsdon, J., Christopher, D.J., 1991. The effect of laser-induced heating upon the vibrational Raman spectra of graphites and carbon fibres. Carbon 29, 133-137.

Ewbank, G., Edwards, D., Abbott, G.D., 1996. Chemical characterization of Lower Devonian vascular plants. Organic Geochemistry 25, 461-473.

Ferralis, N., Matys, E.D., Knoll, A.H., Hallmann, C., Summons, R.E., 2016. Rapid, direct and non-destructive assessment of fossil organic matter via microRaman spectroscopy. Carbon 108, 440-449.

Ferrari, A.C., Robertson, J., 2000. Interpretation of Raman spectra of disordered and amorphous carbon. Physical Review B 61, 14095-14107.

Greenwood, P.F., George, S.C., Pickel, W., Zhu, Y., Zhong, N., 2001. In situ analytical pyrolysis of coal macerals and solid bitumens by laser micropyrolysis GC-MS. Journal of Analytical and Applied Pyrolysis 58-59, 237-253.

Hickman-Lewis, K., Westall, F., Cavalazzi, B., 2020. Diverse communities of Bacteria and Archaea flourished in Palaeoarchaean (3.5-3.3 Ga) microbial mats. Palaeontology 63, $1007-1033$.

Kebukawa, Y., Alexander, C.M.O., Cody, G.D., 2019. Comparison of FT-IR spectra of bulk and acid insoluble organic matter in chondritic meteorites: An implication for missing carbon during demineralization. Meteoritics \& Planetary Science 54, 1632-1641.

Kouketsu, Y., Mizukami, T., Mori, H., Endo, S., Aoya, M., Hara, H., Nakamura, D., Wallis, S., 2014. A new approach to develop the Raman carbonaceous material geothermometer for low-grade metamorphism using peak width: Raman CM geothermometer using FWHM. Island Arc 23, 33-50.

Larsen, J.W., Pan, C.S., Shawver, S., 1989. Effect of demineralization on the macromolecular structure of coals. Energy \& Fuels 3, 557-561.

Ledevin, M., Arndt, N., Simionovici, A., Jaillard, E., Ulrich, M., 2014. Silica precipitation 
triggered by clastic sedimentation in the Archean: New petrographic evidence from cherts of the Kromberg type section, South Africa. Precambrian Research 255, 316334.

Love, G.D., Stalvies, C., Grosjean, E., Meredith, W., Snape, C.E., 2008. Analysis of molecular biomarkers covalently bound within Neoproterozoic sedimentary kerogen. The Paleontological Society Papers 14, 67-83.

Love, G.D., Zumberge, J.A., Cárdenas, P., Sperling, E.A., Rohrssen, M., Grosjean, E., Grotzinger, J.P., Summons, R.E., 2020. Sources of $\mathrm{C}_{30}$ steroid biomarkers in Neoproterozoic-Cambrian rocks and oils. Nature Ecology \& Evolution 4, 34-36.

Mark, D.F., Rice, C.M., Fallick, A.E., Trewin, N.H., Lee, M.R., Boyce, A., Lee, J.K.W., $2011 .{ }^{40} \mathrm{Ar} /{ }^{39} \mathrm{Ar}$ dating of hydrothermal activity, biota and gold mineralization in the Rhynie hot-spring system, Aberdeenshire, Scotland. Geochimica et Cosmochimica Acta 75, 555-569.

Marshall, C.P., Marshall, A.O., 2014. Raman spectroscopy as a screening tool for ancient life detection on Mars. Philosophical Transactions of the Royal Society A: Mathematical, Physical and Engineering Sciences 372, 20140195.

Maslova, O.A., Ammar, M.R., Guimbretière, G., Rouzaud, J.-N., Simon, P., 2012. Determination of crystallite size in polished graphitized carbon by Raman spectroscopy. Physical Review B 86, 134205.

Nguyen, K., Love, G.D., Zumberge, J.A., Kelly, A.E., Owens, J.D., Rohrssen, M.K., Bates, S.M., Cai, C., Lyons, T.W., 2019. Absence of biomarker evidence for early eukaryotic life from the Mesoproterozoic Roper Group: Searching across a marine redox gradient in mid-Proterozoic habitability. Geobiology 17, 247-260.

Preston, L.J., Genge, M.J., 2010. The Rhynie Chert, Scotland, and the search for life on Mars. Astrobiology 10, 549-560. 
Quijada, M., Riboulleau, A., Strother, P., Taylor, W., Mezzetti, A., Versteegh, G.J.M., 2016. Protosalvinia revisited, new evidence for a land plant affinity. Review of Palaeobotany and Palynology 227, 52-64.

Quirico, E., Rouzaud, J.-N., Bonal, L., Montagnac, G., 2005. Maturation grade of coals as revealed by Raman spectroscopy: Progress and problems. Spectrochimica Acta Part A: Molecular and Biomolecular Spectroscopy 61, 2368-2377.

Rice, C.M., Ashcroft, W.A., Batten, D.J., Boyce, A.J., Caulfield, J.B.D., Fallick, A.E., Hole, M.J., Jones, E., Pearson, M.J., Rogers, G., Saxton, J.M., Stuart, F.M., Trewin, N.H., Turner, G., 1995. A Devonian auriferous hot spring system, Rhynie, Scotland. Journal of the Geological Society 152, 229-250.

Rice, C.M., Trewin, N.H., Anderson, L.I., 2002. Geological setting of the Early Devonian Rhynie cherts, Aberdeenshire, Scotland: an early terrestrial hot spring system. Journal of the Geological Society 159, 203-214.

Romero-Sarmiento, M.-F., Rouzaud, J.-N., Bernard, S., Deldicque, D., Thomas, M., Littke, R., 2014. Evolution of Barnett Shale organic carbon structure and nanostructure with increasing maturation. Organic Geochemistry 71, 7-16.

Rouzaud, J.-N., Deldicque, D., Charon, É., Pageot, J., 2015. Carbons at the heart of questions on energy and environment: A nanostructural approach. Comptes Rendus Geoscience $347,124-133$.

Sanei, H., Wood, J.M., Ardakani, O.H., Clarkson, C.R., Jiang, C., 2015. Characterization of organic matter fractions in an unconventional tight gas siltstone reservoir. International Journal of Coal Geology 150-151, 296-305.

Silva, T.F. da, Mendonça Filho, J.G., da Silva, M.C., de Oliveira, A.D., de Souza, J.T., Rondon, N.F., 2016. Botryococcus braunii versus Gloeocapsomorpha prisca: Chemical composition correlation using laser micropyrolysis-gas 
chromatography/mass spectrometer (LmPy-GCMSMS). International Journal of Coal Geology 168, 71-79.

467

468

469

Stout, S.A., 1993. Lasers in organic petrology and organic geochemistry, II. In-situ laser micropyrolysis-GCMS of coal macerals. International Journal of Coal Geology 24, 309-331.

Summons, R.E., Jahnke, L.L., Simoneit, B.R.T., 1996. Lipid biomarkers for bacterial ecosystems: studies of cultured organisms, hydrothermal environments and ancient sediments. In: Evolution of Hydrothermal Ecosystems on Earth (and Mars?). Wiley, Chichester, pp. 174-194.

Summons, R.E., Brassell, S.C., Eglinton, G., Evans, E., Horodyski, R.J., Robinson, N., Ward, D.M., 1988. Distinctive hydrocarbon biomarkers from fossiliferous sediment of the Late Proterozoic Walcott Member, Chuar Group, Grand Canyon, Arizona. Geochimica et Cosmochimica Acta 52, 2625-2637.

Tekely, P., Nicole, D., Delpuech, J. -j., Totino, E., Muller, J.F., 1987. Chemical structure changes in coals after low-temperature oxidation and demineralization by acid treatment as revealed by high resolution solid state ${ }^{13} \mathrm{C}$ NMR. Fuel Processing Technology 15, 225-231.

Trewin, N.H., 2003. History of research on the geology and palaeontology of the Rhynie area, Aberdeenshire, Scotland. Transactions of the Royal Society of Edinburgh: Earth Sciences 94, 285-297.

Vandenbroucke, M., Largeau, C., 2007. Kerogen origin, evolution and structure. Organic Geochemistry 38, 719-833.

Wopenka, B., Pasteris, J.D., 1993. Structural characterization of kerogens to granulite-facies graphite: Applicability of Raman microprobe spectroscopy. American Mineralogist $78,533-557$. 
490

491

492

493

494

495

496

497

498

499

500

501

502

503

504

505

Yoshioka, H., Takeda, N., 2004. Analysis of organic compounds in coal macerals by infrared laser micropyrolysis. Journal of Analytical and Applied Pyrolysis 71, 137-149.

Zhang, L., Li, Z., Yang, Y., Zhou, Y., Kong, B., Li, J., Si, L., 2016. Effect of acid treatment on the characteristics and structures of high-sulfur bituminous coal. Fuel 184, 418429.

\section{Figure captions}

Fig. 1. (a) Typical Raman spectra measured on OHMM (black line) and OLMM (grey line).

Fig. 2. Emissions of (a) hydrocarbons and (b) $\mathrm{CO}_{2}$ during Rock-Eval pyrolysis of OHMM (black line) and OLMM (grey line). The red curve indicates the pyrolysis temperature program. The green area in (b) indicates the temperature interval, for which $\mathrm{CO}_{2}$ emissions are included in the calculation of OI. 
Table 1: Rock-Eval parameters determined in OHMM and OLMM. ${ }^{*} \mathrm{H} / \mathrm{C}$ atomic ratio was estimated using the relationship between $\mathrm{H} / \mathrm{C}$ atomic ratio and $\mathrm{HI}(\mathrm{H} / \mathrm{C}=0.0017 \times \mathrm{HI}+0.453)$ published by Espitalié et al. (1977).

\begin{tabular}{lccccccc}
\hline & $\begin{array}{c}\text { S1 } \\
(\mathbf{m g ~ H C} / \mathbf{g})\end{array}$ & $\begin{array}{c}\mathbf{S 2} \\
(\mathbf{m g ~ H C} / \mathbf{g})\end{array}$ & $\begin{array}{c}\text { TpkS2 } \\
\left.\mathbf{(}{ }^{\circ} \mathbf{C}\right)\end{array}$ & $\begin{array}{c}\text { TOC } \\
(\mathbf{\%})\end{array}$ & $\begin{array}{c}\text { HI } \\
(\mathbf{m g ~ H C / g ~ T O C})\end{array}$ & $\begin{array}{c}\text { OI } \\
(\mathbf{m g ~ C O} / \mathbf{g ~ T O C})\end{array}$ & $\begin{array}{c}\text { H/C } \\
\text { atomic ratio* }\end{array}$ \\
\hline OHMM & 0.59 & 11.76 & 481 & 25.4 & 46 & 59 & 0.53 \\
OLMM & 2.48 & 18.83 & 504 & 27.5 & 68 & 15 & 0.57 \\
\hline
\end{tabular}


Table 2: Raman-derived parameters (mean value \pm S.D.) determined in OHMM and OLMM ( $\mathrm{n}=15$; Wilcoxon rank test).

\begin{tabular}{cccccc} 
& $\mathbf{I}_{\mathbf{D} 1 / \mathbf{I}_{\mathbf{G}+\mathbf{D} 2}}$ & $\mathbf{I}_{\mathbf{D} 4} / \mathbf{I}_{\mathbf{G}+\mathbf{D} \mathbf{2}}$ & $\mathbf{I}_{\mathbf{D} 5} / \mathbf{I}_{\mathbf{G}+\mathbf{D} \mathbf{2}}$ & $\mathbf{a D 4}$ & $\mathbf{\alpha D 5}$ \\
\hline OHMM & $0.58 \pm 0.02$ & $0.38 \pm 0.02$ & $0.43 \pm 0.04$ & $359 \pm 35$ & $-288 \pm 39$ \\
OLMM & $0.52 \pm 0.02$ & $0.36 \pm 0.02$ & $0.31 \pm 0.01$ & $202 \pm 37$ & $-240 \pm 28$ \\
\hline$p$-value & $<0.001$ & $<0.001$ & $<0.001$ & $<0.001$ & $<0.001$ \\
\hline
\end{tabular}




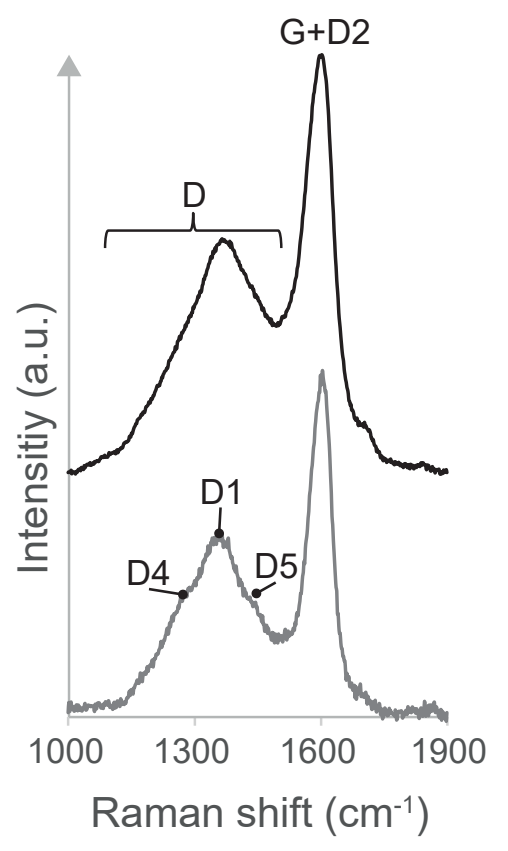



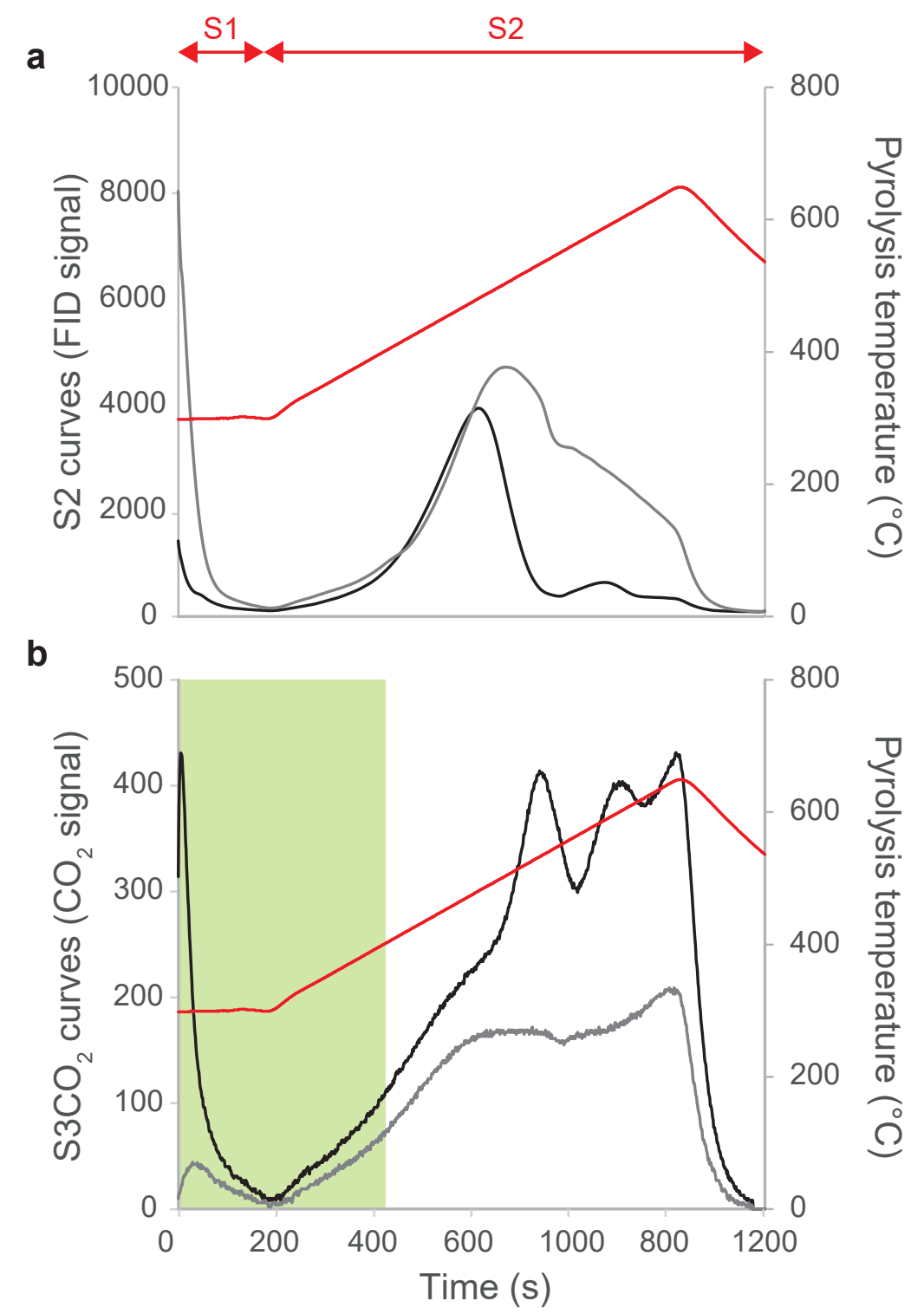